\title{
Article \\ Efficiency management in catch handling onboard small boats- standardisation of processes in Icelandic fisheries
}

Ingibjörg Karlsdóttir ${ }^{1}$, David Cook ${ }^{2}$ and Inga Minelgaité ${ }^{3, *}$

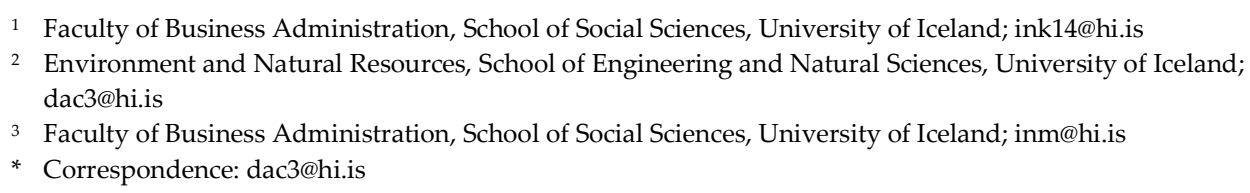

\begin{abstract}
Small boat fishers are often the lifeblood of remote coastal communities in Iceland, contributing to employment, jobs and economic prosperity. This study conducts exploratory but highly practical research into the efficiency of onboard catch handling practices by Icelandic small boat fishers using fish handling tools called automatic jigging machines. Using applied research methods, this study researches whether standardisation of operations could be applied to make catch handling practices on small boats more time and resource efficient, leading to reduced waste, a consistently higher quality product, and potential increases in economic efficiency and sustainability. Thematic analysis, value stream mapping, flow analysis and Kaizen ideology were adopted to identify gaps and continuous improvement opportunities to standardise processes, leading to exemplary performance. Eight core recommendations are identified, seven of which are classed as straight-forward, 'do now' measures according to a Kaizen Priority Matrix. These include human and technological interventions in the areas of safety, organisational arrangements, hygiene, fish handling and bleeding, and cooling. Questionnaire responses reveal four main themes of importance to the sub-sector: changes in recent decades; the importance of small boat fishers; education and improvement; and the particularities of the sub-industry. The latter include the perception of a 'race against time' to land the catch, an issue that sometimes contributes to sub-optimal catch handling practices. Although this study has decidedly practical connotations for small boat fishers, its outcomes are also likely to be of interest to academics, particularly those focused on the organisational management of natural resources and general applications of the project management methodology and applied research methods as a means of solving practical problems in everyday life.
\end{abstract}

Keywords: Sustainability; Processes; Small boats; Catch handling; Standardisation of operations; Efficiency.

\section{Introduction}

The fishing industry is one of the most important sectors in Iceland, constituting the nation's largest source of export revenue (more than 40\%) until 2015, when the sector was surpassed in significance by tourism [1]. Annual average caches over the past 30 years, the era since the introduction of Individual Transferable Quotas, have been around 
1.5 million metric tonnes [2] The industry has been described as exemplary in its utilisation of catch and achievement of economic efficiency and profit maximisation objectives $[3,4,5,6,7,8]$, and in so doing contributes to the nation's pursuit of the Sustainable Development Goals [8, 9].

Small boats in the Icelandic fishing industry contribute to important job creation in the countryside, returning catch value to Icelandic society and ensuring diversity in the fisheries sector [10,11, 12]. There has been a considerable increase in the catch of small boats in recent years. According to Landssamband smábátaeigenda (National Association of Small Boat Owners) [13], the total catch of small boats was 92,818 tonnes during the year 2015, an increase of nearly 10,000 tonnes from only two years before. Small boat fishing is particularly important for sustaining the populations and viability of remote coastal communities in Iceland, such as the Westfjords, where these boats may account for nearly all the local landings [11, 14] and there are few other industries beyond aquaculture [15].

From the past to the present day on a global scale, small-scale fisheries have been presented as an activity characterised by low productivity and low yield rates. The survey results of [16] identified relatively low levels of economic efficiency among Mediterranean fisheries, and that the same outputs could be achieved if the inputs were reduced by an average of $36.1 \%$. More recently, the study of Gunnlaugsson et al. [17] found that Iceland's coastal fisheries have been making small economic losses, whereas other fisheries in Iceland have on average been profitable. In addition to concerns about economic efficiency, there is evidence that small-scale fisheries have typically been ignored by scientists and policy-makers when compared with industrialscale fisheries $[18,19,20]$. Given this context, it is perhaps unsurprising that despite the presence of over 2,000 small boats in the Icelandic fleet [14], there are no standardised rules or regulations concerning how the catch is handled onboard, apart from recognition that the process involves the eventual landing of the catch [14,21]. Standards are a select type of rules or processes, which, when focused on optimisation, can be associated with several advantages for operators, such as helping to ensure consistency of product quality, delivering efficiency savings in time and resources, increasing productivity, and cultivating a positive external image [22].

This study sets out to evaluate onboard catch management among small boat fishers against best practice benchmarks, which are developed through use of Kaizen ideology, a widely adopted Japanese approach for facilitating an evaluation of the extent to which there are performance shortfalls and opportunities to standardise exemplar operational processes [23, 24, 25, 26]. These measures could lead to waste reduction, increase catch value and economic efficiency (helping to sustain jobs and livelihoods), and potentially contribute to the pursuit of broader, sustainability-related ambitions by Icelandic small boat fishers. Thus, this paper poses the following research question: can standardisation of operations be used to make catch management on small boats more efficient in Iceland? This study will answer the question through specific focus on small boat fishing using handline fishing tools called automatic jigging machines. Special licenses are needed for coastal jigging, and this type of fishing is subject to strict conditions, including vessel operators being restricted to ownership of one boat, only four automatic jigging reels are permitted onboard each vessel, and a maximum catch per trip of $774 \mathrm{~kg}$ of species per trip (ungutted cod equivalent) (Interview data, 2020).

This paper is structured as follows. Section 2 provides background information concerning the definition of small boat fishing in Iceland and catch handling practices, including an outline of best practice steps in onboard catch management, and details the contribution that more efficient catch handling can potentially make with respect to the Sustainable Development Goals. Section 3 describes the applied research methods that were adopted in this study. Section 4 articulates the results from the video analysis and questionnaires. Section 5 discusses the main implications, especially the efficiency opportunities emerging from potential 
standardisation of processes, and provides a brief conclusion, summarising the main recommendations and considering options for future research.

\section{Background}

2.1 Definition of small boats and coastal jigging

According to Landssamband smábátaeigenda [13], the National Association of Small Boat Owners in Iceland, the following types of boats fall under small boats: small boats with catch limit, coastal fishing boats, hook catch limit boats, grayling boats, and mackerel boats. As determined by the Fisheries Management Act, the law no. 116/2006, as amended 82/2013 [27], only boats shorter than 15 meters and less than 30 gross tons can obtain a fishing license with a hook catch limit. TACs (Total Allowable Catch) can be of two types, i.e., general catch limit and hook catch limit. A boat with a hook catch limit may only use hook fishing gear to engage in fishing, either hand gear or line [28].

The coastal jigging system of focus in this paper in operated from May through to August, allowing fishing of demersal species limited by an annual total allowable catch and operator-specific Jigging and Line (J \& L) quotas [14]. In 2016, there were around 600 vessels in Iceland that reported catches with this system, most of which were solely allowed to fishing gear with hooks [29]. The vessels are mainly long-liners that are 8-12 metres long and under 15 GT. Since June 2013, the upper limits are 15 metres in length and 30 GT, however, in 2018, there were only 20 vessels that were close to these new thresholds [30\}.

\subsection{Catch handling}

By cooling the fish, it can be kept alive longer. Fish that has been cooled right after being caught has more vitality when it comes to bleeding, and blood emptying will be enhanced. The fish must be cooled as close as possible to the melting point of ice before being arranged into tubs [21,31]. Proper handling has a major impact on the fish's quality as the shelf life can be shortened if gutting and washing is poorly done [21]. As stated by Matís [31] (p. 43), "It has become common for the catch of small boats to be gutted ashore, but good bleeding and adequate cooling must be ensured". The intestines of the fish are also considered valuable; however, it varies whether the fish is both handled for bleeding and gutted or only handled for bleeding onboard small boats [21].

\subsection{Deterioration of quality}

Fillets are said to be loose when the muscle layers separate so that cracks or holes form in the flesh [21]. There is a risk of loosening in the fillet when a whole fish stiffens. It happens when the muscles constrict but do not shrink because the fish's skeleton does not slack. When the tension in the muscle layers relaxes, looseness forms in the flesh of the fish [21].

Tryggvason [32] examined the effect of drop heights on icefish trawlers. The summary states that the drop height can probably result in bruising of a fish, but the drop height in that study is 1.5 meters. However, it is noted that another possible reason for bruising is that the fish must roll down a ladder in icefish trawlers, which it is not standard equipment in small boats. There is a chance of internal bruising if the fish has been poorly drained. Still, if the blood drainage has been adequately done, internal bruising does not form, only loosening in the flesh [21]. 
It is easy to bend a fish immediately after its death, but if the fish is in rigor, which occurs shortly after its death, the muscles begin to stiffen and harden. It is essential not to straighten a rigid fish in the rigor stage [21]. When a fish is in rigor, it is more difficult to bleed or gut the fish. If a fish is in rigor, there is a risk that blood drainage is not sufficient, and it is more difficult to arrange the fish into the fish tub. There is also a greater likelihood of loosening in the flesh upon impact or increased pressure during rigor [21]. Therefore, it is crucial to have it well bled and gutted if that action is to be done onboard before it goes into rigor to maintain the end product's quality.

2.4 The process of catch handling on small vessels

The elements of catch handling and quality management form core aspects of best practice onboard catch management. Fig. 1 embeds the main considerations in a flow diagram, which has been sourced from Matís [31] and Pálsson [33]. This process was developed to form a theoretical understanding of best practice standards, which can later be compared to actual onboard catch handling practices among small boat fishers in Iceland. The process unveils each stage if the fish is bled and gutted in the same operation, or, alternatively, if it is only handled for bleeding. As small boats usually arrive at the port on the same day as the fishing, the fish is often not gutted onboard, but the fish's intestines are valuable, and therefore ungutted fish is often sold in fish markets for a higher price. Therefore, it can be assumed that fish are usually not gutted onboard small boats but ashore where there are appropriate facilities for this task. 
Appropriate catch handling

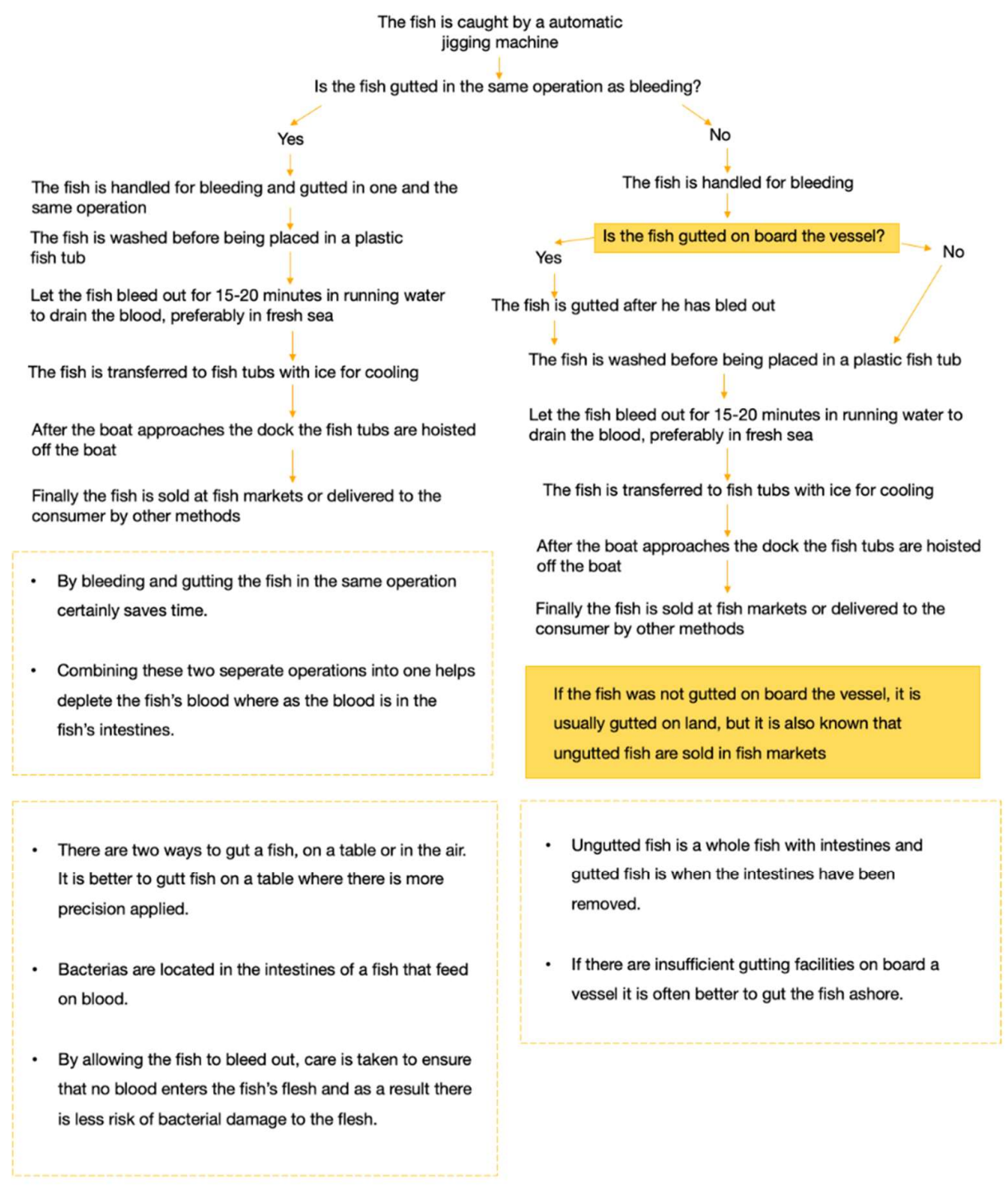

Figure 1. Efficient catch handling processes onboard smaller boats.

2.5 Onboard process management and relationships to sustainability

In recent years, there is increasing evidence that small boat fishers operate within complex political, cultural and historical contexts, and often have motivations that go beyond purely economic objectives, such as profit maximisation and job creation [10]. There is evidence that small-scale fishers around the world, including in Iceland, are "important to maintaining community sustainability through flexible arrangements that respond to social and environmental conditions" [10] (p. 70). As such, it is evident that there is an intertwining of the economic efficiency goals of small boat fishers with wider objectives, which nowadays include the pursuit of the United Nations' Sustainable Development Goals (SDGs) [34] at the local, regional, national and global scale [35]. Although the SDGs are seventeen in total, the authors of this paper have identified five main goals (SDGs, 4, 9, 12, 13 and 14) (see Table 1) which are linkable to the concept of economic efficiency. This delineation also helps to place the results in the context of Iceland's sustainability objectives to be fulfilled by the year 2030 . 
Table 1. Icelandic small boat fishers, economic efficiency and related SDGs

\begin{tabular}{|c|c|c|}
\hline SDG & $\begin{array}{l}\text { Relevance to Icelandic small boat fishing and } \\
\text { enhanced onboard catch management } \\
\text { procedures }\end{array}$ & SDG Targets of Greatest Relevance \\
\hline $\begin{array}{l}\text { 4: Quality } \\
\text { education }\end{array}$ & $\begin{array}{l}\text { The goal of this project is to design standard } \\
\text { procedures for catch handling, in so doing } \\
\text { reducing waste. Even though a great deal of } \\
\text { information is available about what is needed } \\
\text { to maintain fish products' freshness, } \\
\text { consumers' expectations are often not met } \\
\text { because something goes wrong in the process } \\
\text { [33]. The quality education goal is, in fact, } \\
\text { central to ensuring success in increasing the } \\
\text { efficiency of catch management because those } \\
\text { who work at sea are those who can contribute } \\
\text { to achieving the practical goals of this study. }\end{array}$ & $\begin{array}{l}\text { By 2030, ensure that all learners acquire } \\
\text { the knowledge and skills needed to } \\
\text { promote sustainable development, } \\
\text { including, among others, through } \\
\text { education for sustainable development } \\
\text { and sustainable lifestyles }\end{array}$ \\
\hline $\begin{array}{l}\text { 9: Industry, } \\
\text { innovation and } \\
\text { infrastructure }\end{array}$ & $\begin{array}{l}\text { The study's innovative value concerns the } \\
\text { potential for new procedural } \\
\text { recommendations to be implemented by small } \\
\text { boat fishers. The benefits of the project are that } \\
\text { the utilisation of the fish resource will become } \\
\text { more efficient through standardising } \\
\text { procedures in accordance with best practice. }\end{array}$ & $\begin{array}{l}\text { By 2030, upgrade infrastructure and } \\
\text { retrofit industries to make them } \\
\text { sustainable, with increased resource-use } \\
\text { efficiency and greater adoption of clean } \\
\text { and environmentally sound } \\
\text { technologies and industrial processes, } \\
\text { with all countries taking action in } \\
\text { accordance with their respective } \\
\text { capabilities }\end{array}$ \\
\hline $\begin{array}{l}\text { 12: Responsible } \\
\text { consumption and } \\
\text { production }\end{array}$ & $\begin{array}{l}\text { According to the UN [34], } 13.8 \% \text { of food is lost } \\
\text { in supply chains, i.e., via the transport, } \\
\text { storage, and processing of resources. } \\
\text { Therefore, the practical aims of this study are } \\
\text { aligned with SDG 12, since responsible } \\
\text { production is tied to enhanced utilisation and } \\
\text { reduced waste of the resource. }\end{array}$ & $\begin{array}{l}\text { By 2030, achieve the sustainable } \\
\text { management and efficient use of natural } \\
\text { resources } \\
\text { By 2030, halve per capita global food } \\
\text { waste at the retail and consumer levels } \\
\text { and reduce food losses along } \\
\text { production and supply chains, } \\
\text { including post-harvest losses } \\
\text { By 2030, substantially reduce waste } \\
\text { generation through prevention, } \\
\text { reduction, recycling and reuse }\end{array}$ \\
\hline 13: Climate action & $\begin{array}{l}\text { The fishing industry is one of the main } \\
\text { industries that will need to be targeted in } \\
\text { order for Iceland to satisfy its Paris Agreement } \\
\text { target of a } 30 \% \text { reduction in greenhouse gas }\end{array}$ & $\begin{array}{l}\text { Improve education, awareness-raising } \\
\text { and human and institutional capacity on }\end{array}$ \\
\hline
\end{tabular}


emissions by 2030, and the Icelandic climate change mitigation, adaptation,

Government's net zero carbon ambition by

impact reduction and early warning

2040 [36]. Reductions in greenhouse gas

emissions can be affected by small boat fishers

through more efficient onboard catch

management processes, reducing discards, waste and unnecessary fuel consumption.

$\begin{array}{ll}\text { 14: Life below } & \text { Emphasis is placed on the protection of the By 2020, sustainably manage and } \\ \text { water } & \text { resource in SDG 14, and through more protect marine and coastal ecosystems } \\ & \text { sustainable management practices, more fish to avoid significant adverse impacts, } \\ & \text { will return to land and of higher quality, including by strengthening their } \\ & \text { which will likely increase the economic resilience, and take action for their } \\ & \text { efficiency of small boat fishers. } \\ & \text { and productive oceans }\end{array}$

\section{Methodology}

3.1 Applied research using the product management methodology

The project management methodology can be used to develop new products and fix methods that need updating [37]. Project management aims to anticipate or predict hazards or problems by planning and monitoring activities [38]. Therefore, the project management methodology was considered suitable for this study, using applied research methods. Applied research aims to understand and address issues in daily life, discovering practically significant relationships or effects. What characterises applied research is that the environment that needs to be examined often involves multiple layers of analysis. Applied research concentrates on the construct of effects, where several types of measurements are used to look at occurrences in an overall context [39].

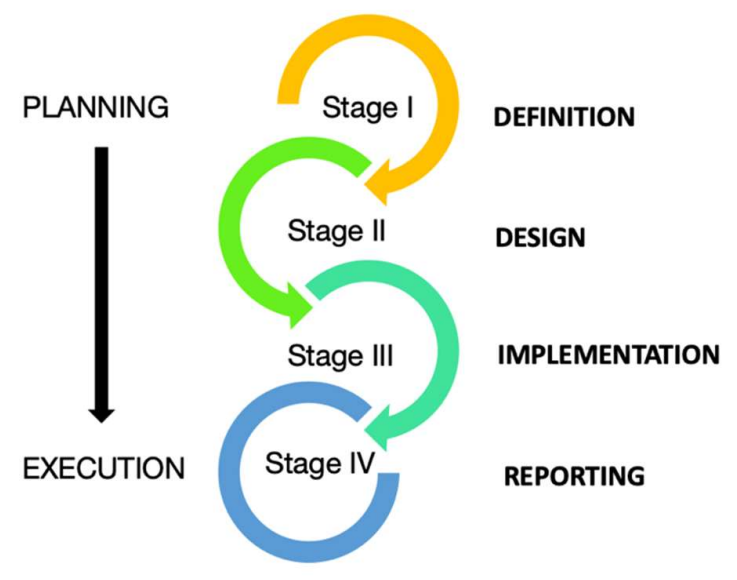

Figure 2. Applied research model (Sourced from Hedrick et al. [39]).

As illustrated in Figure 2, Hedrick et al. [39] depict four stages to applied research from planning through to execution. In the first stage, the issue needs to be defined, and a research question prepared. The second stage is where a research plan is designed. Stage three is an implementation stage, during which data is collected and the results are assembled. Stage four is reporting of the main 
outcomes, including interpretation of significance and generalisability, and identification of recommendations for process enhancement.

\subsection{Data collection and analysis}

Data was collected and analysed as follows. Firstly, available data sources were used to examine onboard processes and specify the problems in catch management on small boats. Videos from the streaming service YouTube [40, 41, 42, 43] were studied. These were selected on the basis that each video included a camera (go-pro or similar) which was located so that most or all of the boat was visible, and therefore it was possible to identify and reflect on the on board process activities.

Data was collected from the videos, with a sequential focus on thematic analysis, value stream mapping, flow, continuous improvement, and development of a priority matrix. Value stream mapping is a series of necessary actions to produce a product or service [44]. Value stream analysis can help to identify the wastages that takes place in any process. The flow stage was applied to identify ways in which tools and facilities could be arranged onboard, increasing time and process efficiency. This was carried out using spatial arrangement plans for the four boats, which were drawn up in a simple way on a computer. From this analysis and the initial theoretical framework set out by Matís [31] and Pálsson [33], it was possible to construct exemplar onboard spatial arrangement plans, a template that facilitated deeper gap analysis and identification of opportunities for continuous improvement.

Next, Kaizen ideology was applied. This approach was considered best for finding ways to standardise processes and generate enhancement recommendations, since it has the capacity to measure the scale of a problem and identify the most obvious opportunities for continuous improvement through a priority matrix [23]. Although Japanese in origin, it has nowadays been widely applied in the standardisation and continuous improvement of multiple project-specific processes in business and social contexts, especially relating to quality and safety issues $[23,24,25,26]$.

Finally, a plan was also hatched to go on small boats to compare methods (ordinary versus standardised according to exemplary processes) and collect in-person observations of the time taken to complete each step in the onboard catch handling process. Unfortunately, the onset of COVID-19 in Iceland in March 2020 prevented this stage of the research. Instead, a questionnaire was sent out by e-mail to potential participants. The questionnaire included nine questions, with focus on the importance of the industry, what is already done well and how improvements could be attained onboard catch handling practices on small boats. The questions also sought to glean further insights into how management regulations influenced onboard catch handling operations. The written content of questionnaire responses was thematised in accordance with the best practice approach set out by Creswell [45].

\subsection{Participants}

Table 2 below lists the characteristics of the boats used by the anonymised four small boat fishers in the video analysis part of the methodology. All four individuals were male and were alone onboard. In the following results section, the small boat fishers are referred to as 'Individual 1, Individual 2 ...etc'.

Table 2. Small boat characteristics and equipment.

\begin{tabular}{lllllll}
$\begin{array}{l}\text { Number of } \\
\text { persons } \\
\text { onboard }\end{array}$ & $\begin{array}{l}\text { Type } \\
\text { handline }\end{array}$ & $\begin{array}{l}\text { of } \\
\text { handline } \\
\text { boxes }\end{array}$ & equipment & Workwear & $\begin{array}{l}\text { Other tools } \\
\text { used }\end{array}$ \\
\hline
\end{tabular}




\begin{tabular}{|c|c|c|c|c|c|c|}
\hline Individual 1 & One & $\begin{array}{l}\text { Four } \\
\text { automatic } \\
\text { jigging } \\
\text { machines }\end{array}$ & Two & None & $\begin{array}{l}\text { Gloves, sea } \\
\text { jacket, sea } \\
\text { trousers and } \\
\text { hat }\end{array}$ & $\begin{array}{l}\text { Gaff and a } \\
\text { knife }\end{array}$ \\
\hline Individual 2 & One & $\begin{array}{l}\text { Four } \\
\text { automatic } \\
\text { jigging } \\
\text { machines }\end{array}$ & Two & None & $\begin{array}{ll}\text { Gloves, sea } \\
\text { jacket, sea } \\
\text { trousers and } \\
\text { hat }\end{array}$ & $\begin{array}{l}\text { A knife and } \\
\text { an unused } \\
\text { hook }\end{array}$ \\
\hline Individual 3 & One & $\begin{array}{l}\text { Three } \\
\text { automatic } \\
\text { jigging } \\
\text { machines }\end{array}$ & Two & Rubber mat & $\begin{array}{l}\text { Gloves and } \\
\text { sea trousers }\end{array}$ & $\begin{array}{l}\text { Gaff and } \\
\text { knife }\end{array}$ \\
\hline Individual 4 & One & $\begin{array}{l}\text { Four } \\
\text { automatic } \\
\text { jigging } \\
\text { machines }\end{array}$ & None & None & $\begin{array}{l}\text { Gloves, sea } \\
\text { jacket, sea } \\
\text { trousers and } \\
\text { hat }\end{array}$ & $\begin{array}{l}\text { A knife and } \\
\text { an unused } \\
\text { hook }\end{array}$ \\
\hline
\end{tabular}

A questionnaire was sent via e-mail to eight individuals working in Icelandic small boat fishing. A convenience sample was used as it was considered the most suitable to get information-rich answers due to their industry-specific knowledge. Four completed questionnaires were received. Equal gender ratios were ensured when sending the e-mails, but only one of the four women responded, and three of the four men.

Ethical considerations were made, following the recommendations of Bryman and Bell [46] for conducting quantitative research. All personal data was stored on password protected computers and the anonymity of participants was ensured.

\section{Results}

The following section summarises the results that emerged from the analysis of the data. In the first part (4.1), the results from the YouTube videos are presented, and this follows the outlined process of thematic analysis, value stream mapping, flow, continuous improvement, and development of a priority matrix. The second part (4.2) provides a thematic summary of the outcomes from the questionnaires. Themes identified in 4.1 and 4.2 overlap to some extent but are not directly related.

\subsection{Results from video analysis}

\subsubsection{Thematic analysis}

The data from the four videos were thematically analysed, and one core theme emerged: problems and opportunities. The following thematic analysis will be used to identify the problems that occur onboard boats and therein the opportunities for improving catch management onboard. Table 3 further groups the problems and opportunities into sub-categories of physical, quality and order issues.

Table 3. Problems and opportunities. [40, 41, 42, 43]. 


\begin{tabular}{|c|c|c|c|c|c|c|c|c|c|c|c|c|c|c|c|c|c|}
\hline \multicolumn{18}{|c|}{ Problems and opportunities } \\
\hline & \multicolumn{3}{|c|}{ Physical } & \multicolumn{9}{|c|}{ Quality } & \multicolumn{5}{|c|}{ Order } \\
\hline & 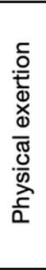 & 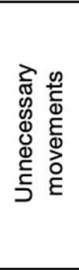 & 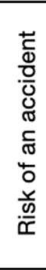 & 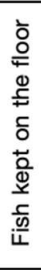 & 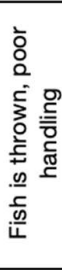 & 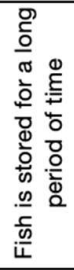 & 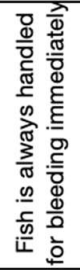 & 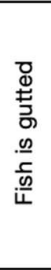 & 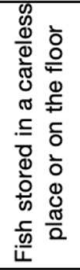 & 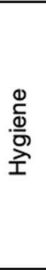 & 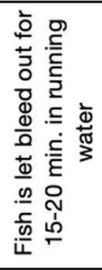 & 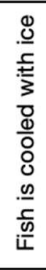 & 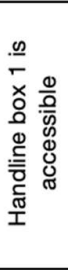 & 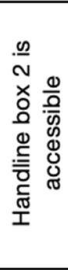 & 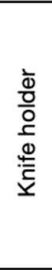 & 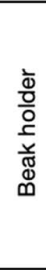 & 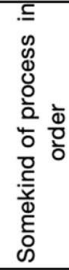 \\
\hline Individual no. 1 & $\mathbf{x}$ & $x$ & $\mathbf{x}$ & $\mathrm{x}$ & & $\mathbf{x}$ & & & $x$ & $x$ & & $?$ & & $\bar{x}$ & & & $\mathbf{x}$ \\
\hline Individual no. 2 & $x$ & & $x$ & & $x$ & & $\mathbf{x}$ & & & 1 & & $x$ & $\mathbf{x}$ & $x$ & $\mathbf{x}$ & & $x$ \\
\hline Individual no. 3 & $\mathbf{x}$ & & $\mathbf{x}$ & & $\bar{x}$ & & $\bar{x}$ & & & $\mathbf{x}$ & & $\mathbf{x}$ & $\bar{x}$ & $\bar{x}$ & $\bar{x}$ & $\mathbf{x}$ & $x$ \\
\hline Individual no. 4 & $x$ & $\bar{x}$ & $\mathbf{x}$ & $\mathbf{x}$ & $\bar{x}$ & $\bar{x}$ & & & $\mathbf{x}$ & & & & & & & & \\
\hline
\end{tabular}

The main observation in the physical sub-category was the commonality that this is difficult physical work. There is a certain risk of accidents that an individual is not stuck to a lifeline or in a sailing buoyancy aid. With regards to quality issues, it was evident that there was also consistency regarding the fact that all of the fishers did not gut the fish onboard, however, this is likely due to inadequate facilities, time savings, and often higher prices for ungutted fish [47]. All individuals placed fresh seawater in fish tanks where the fish were stored. Still, there was insufficient inflow of fresh seawater into the tanks for this operation to be considered satisfactory or consistent. For example, individual no.1 let the sea flow into a fish tank for 28.01 seconds, while individual no. 4 let the sea flow for a total of only 4.29 seconds. Two of the four individuals kept the fish on the deck's floor instead of a handline box. Individual no. 4 had no handline box onboard the boat, and therefore the fish were not appropriately stored immediately after they were caught, leading to the potential for deteriorating quality. In individual no. 1's case, there were two handline boxes onboard, but only one handline box used, and therefore, fish were stored on the floor of the deck when they were newly caught and often longer than that. Three of the individuals discarded or threw the fish around.

\subsubsection{Value stream mapping}

In the following visual analysis (Figures 3 to 6), the steps in catch handling process are reviewed with a respect to each fisher. This is conducted with a view to identifying process whereby there is unnecessary waste, both time and resource inefficiencies which could potentially be improved. 


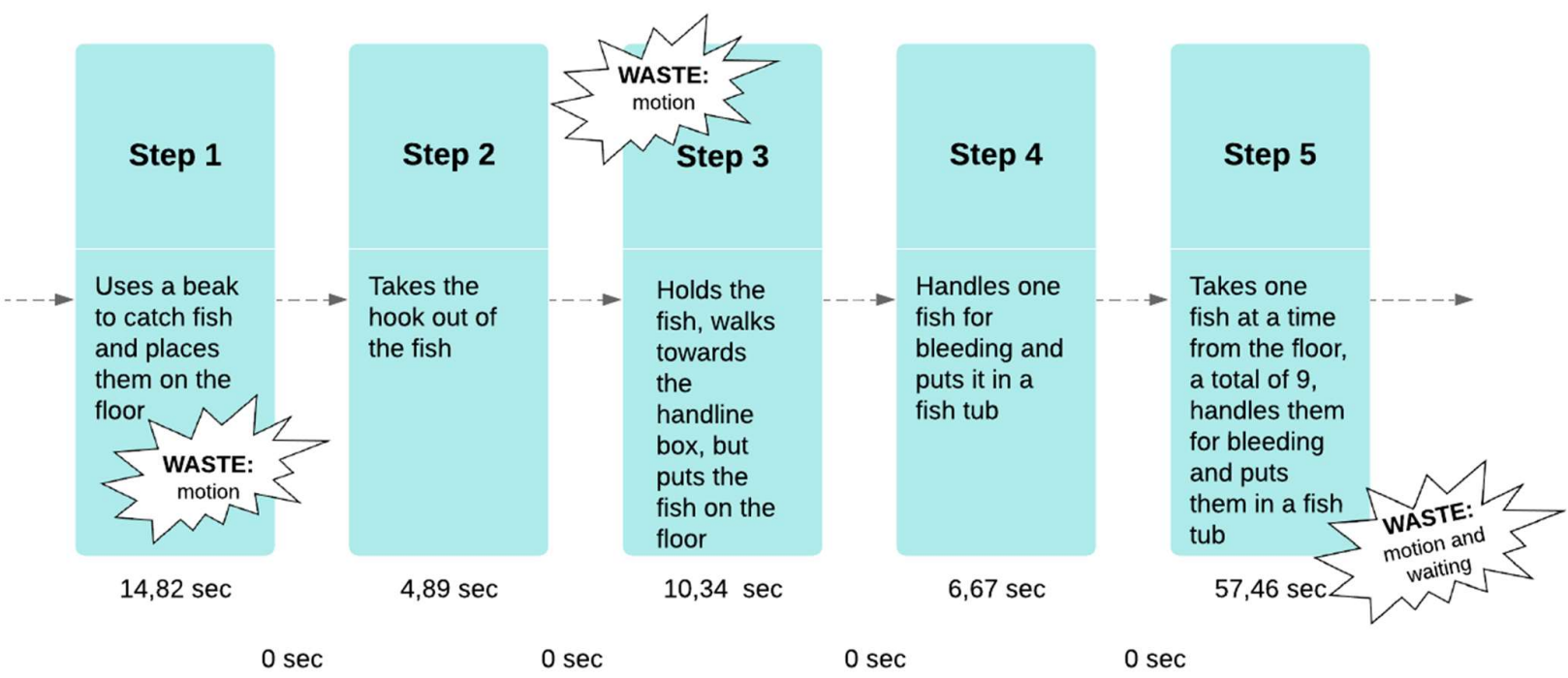

Figure 3. Value stream mapping analysis, Individual 1.

The main waste seen in Figure 3 is the movement and waiting time until the fish is handled for bleeding. It would be possible to have more handline boxes to prevent an individual from making multiple and repeated unnecessary movements. Bending to pick fish off the floor is an excessive movement that could be solved by having a handline box in an accessible location onboard. Individual 1 had two handline boxes onboard, but handline box number 2 was the only one in an accessible location, as had been stated in Table 3 . If both were in an accessible position, individual no. 1 would not have had to bend down multiple times to pick up the fish lying on the boat's deck to move them closer to the fish tub. This would have saved both time and physical exertion, and the fish that lay on the boat's deck could have been handled for bleeding sooner. 


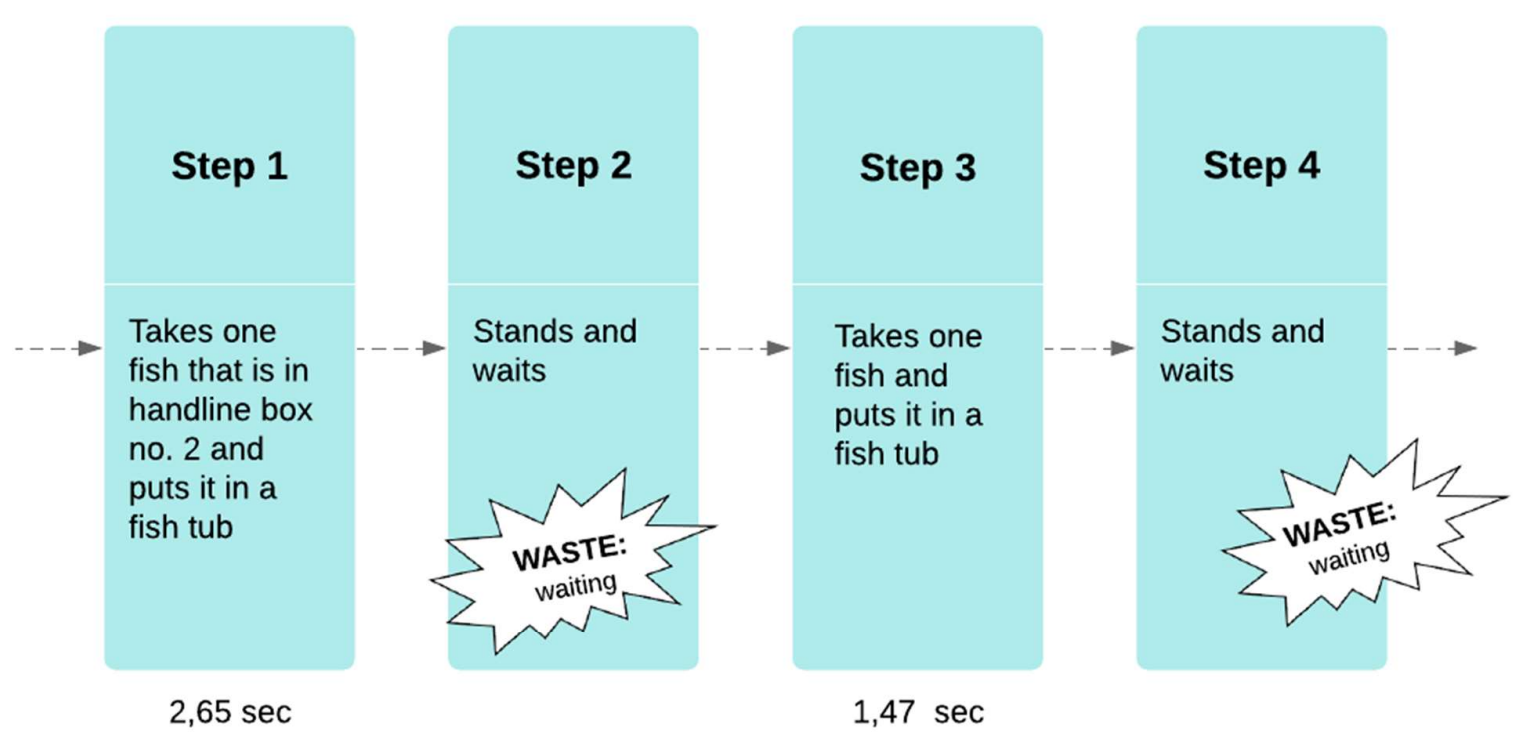

Wait $4,05 \mathrm{sec}$

Wait $5,84 \mathrm{sec}$

The video is fast-forwarded very fast so the seconds are based on the video itself and not real time

Figure 4. Value stream mapping analysis, Individual no. 2.

The main waste revealed in Figure 4 is the wait between the time the fish was caught and placed in the fish tub. However, while Individual no. 2 was waiting, it was possible to clean the boat's deck and thus take care of its hygiene. There was also time to make sure that there was a fresh inflow of seawater in the bleeding tub, and when the fish had bled out well enough, they could be transferred to a tub with ice. The video was fast-paced, and therefore it was not possible to realise how long the wait was in realtime. Although the standby time was 4.05 and 5.84 seconds, respectively, according to the valuation, this could have been 30 seconds or more in real-time. It is possible to do many things in 30 seconds or more that improve catch handling and save time through repeated processes over the duration of a day's fishing. 


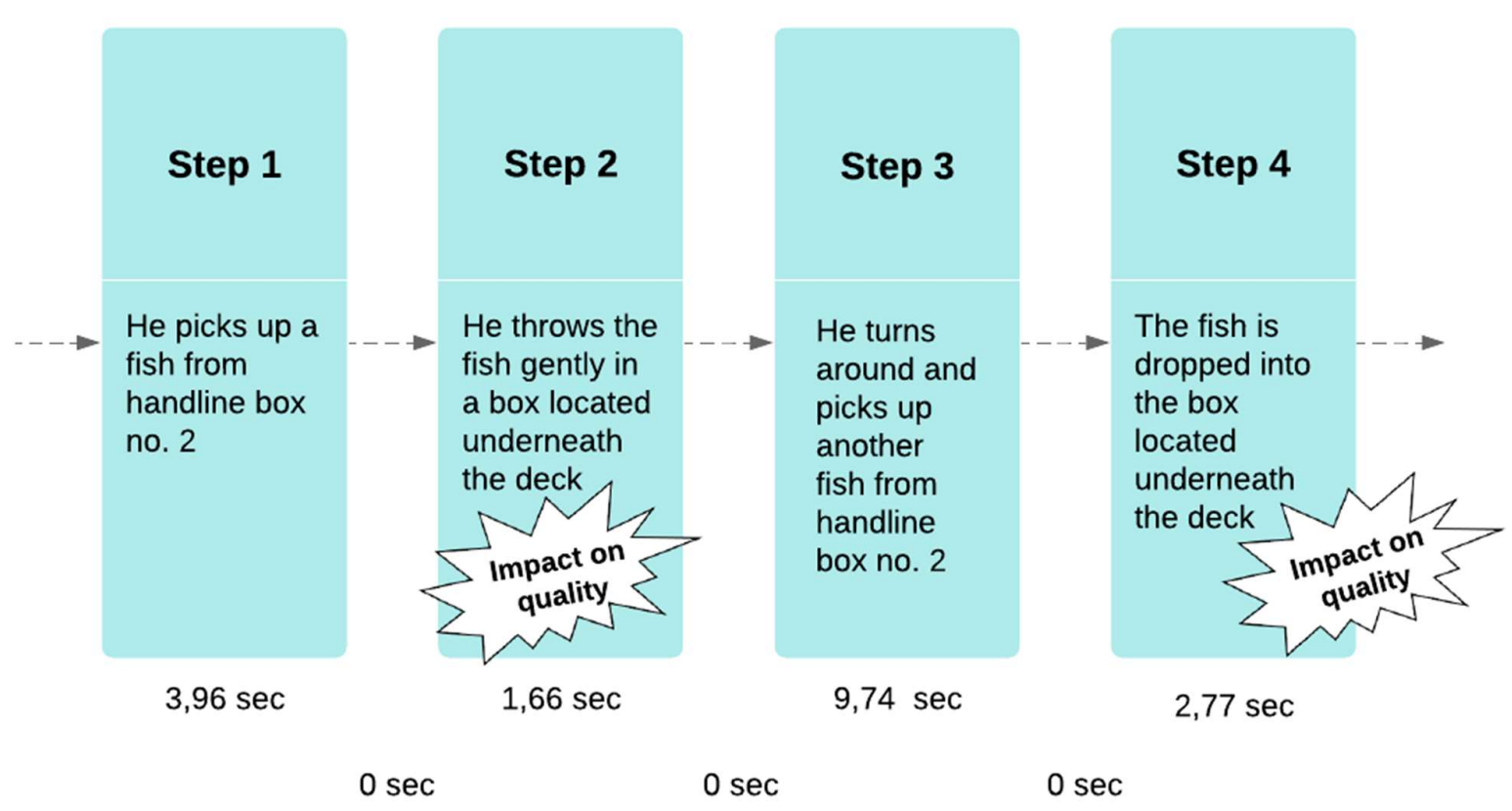

Figure 5. Value stream mapping analysis, Individual no. 3.

No time inefficient processes were observed with respect to Individual no. 3 in Figure 5. However, on certain occasions the fish was dropped into fish tubs. High speed is prominent in small boat fishing, and it is necessary always to be alert when a new fish bites the line. The race against time could be why the fish is sometimes dropped instead of being carefully discarded, but the fish's fall can affect the quality of the landed fish. 


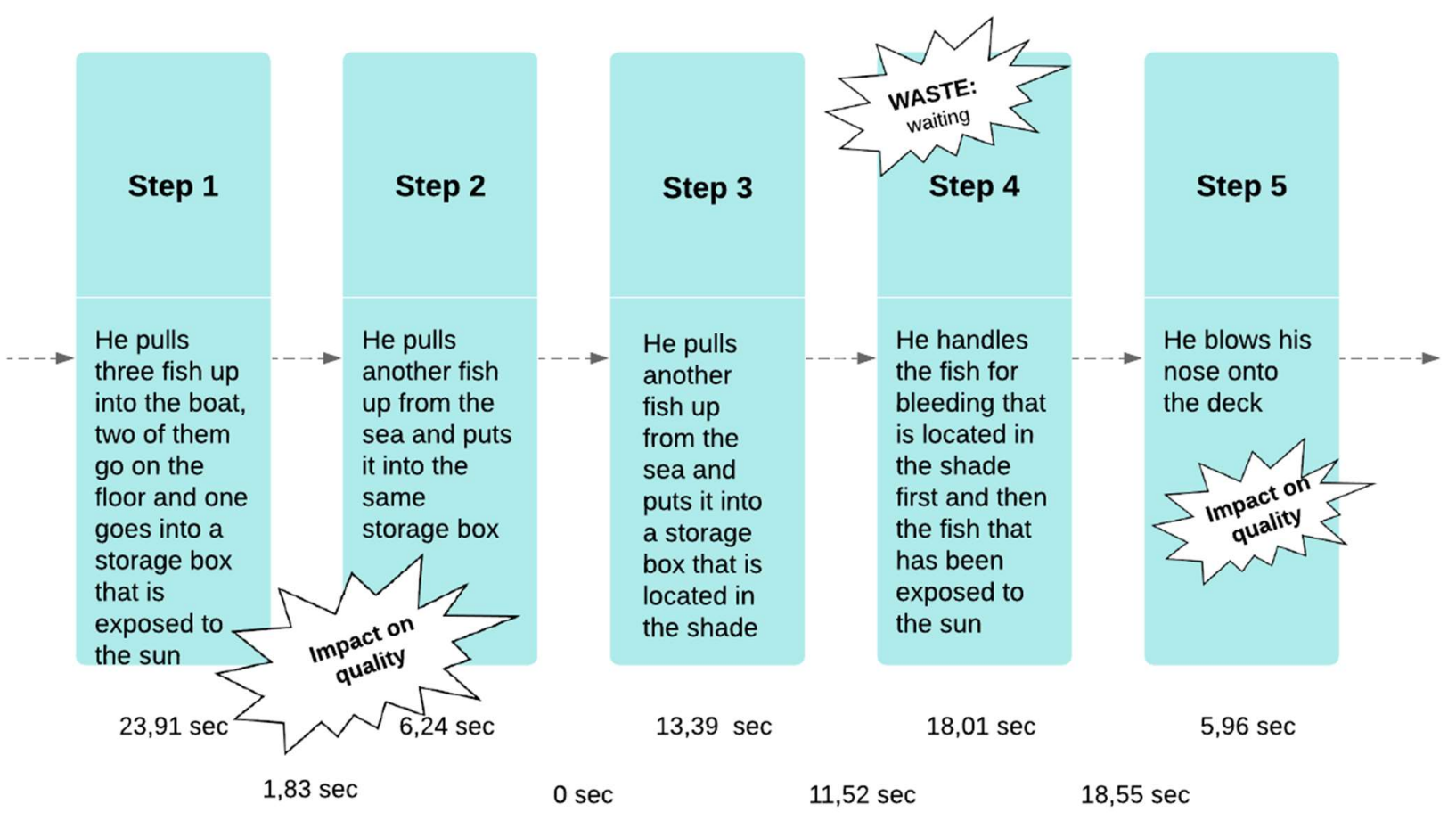

Figure 6. Value stream mapping analysis, Individual no. 4.

With respect to Individual no. 4, there are opportunities for enhancement according to Figure 6, which relate to the waiting time and hygiene that affects the quality of the final product. The fish was often placed directly on the deck or stored in tubs, either in the sun or in the shade and in a time inefficient manner. Temperature can also affect the quality of the fish as well as hygiene. Step 5 shows that Individual no. 4 blew their nose on the deck, where the fish had laid before. Hygiene is crucial when it comes to catch treatment, as stated by Matís [48] (p. 2): "All surfaces that are in direct contact with the raw material, such as tubs and boxes, must be clean". This also applies to decks in this case where a handline box is not used to store the fish.

Overall, the value stream analysis provided a useful means of identifying time inefficient processes and actions by fishers that potentially undermine the quality of the fish. The main observed problems were the time inefficient practices, especially relating to excessive movement, and actions that affect quality, such as the dropping of fish, poor storage and sub-standard hygiene practices.

\subsubsection{Flow}

Increased flow can save time and increase efficiency. This part of the results constructs spatial arrangement plans (Figures 7 to 10) for each of the four boats, which are created to highlight both the deficiencies observed in the thematic and value stream mapping stages of the analysis, and also cases of exemplar practice. 


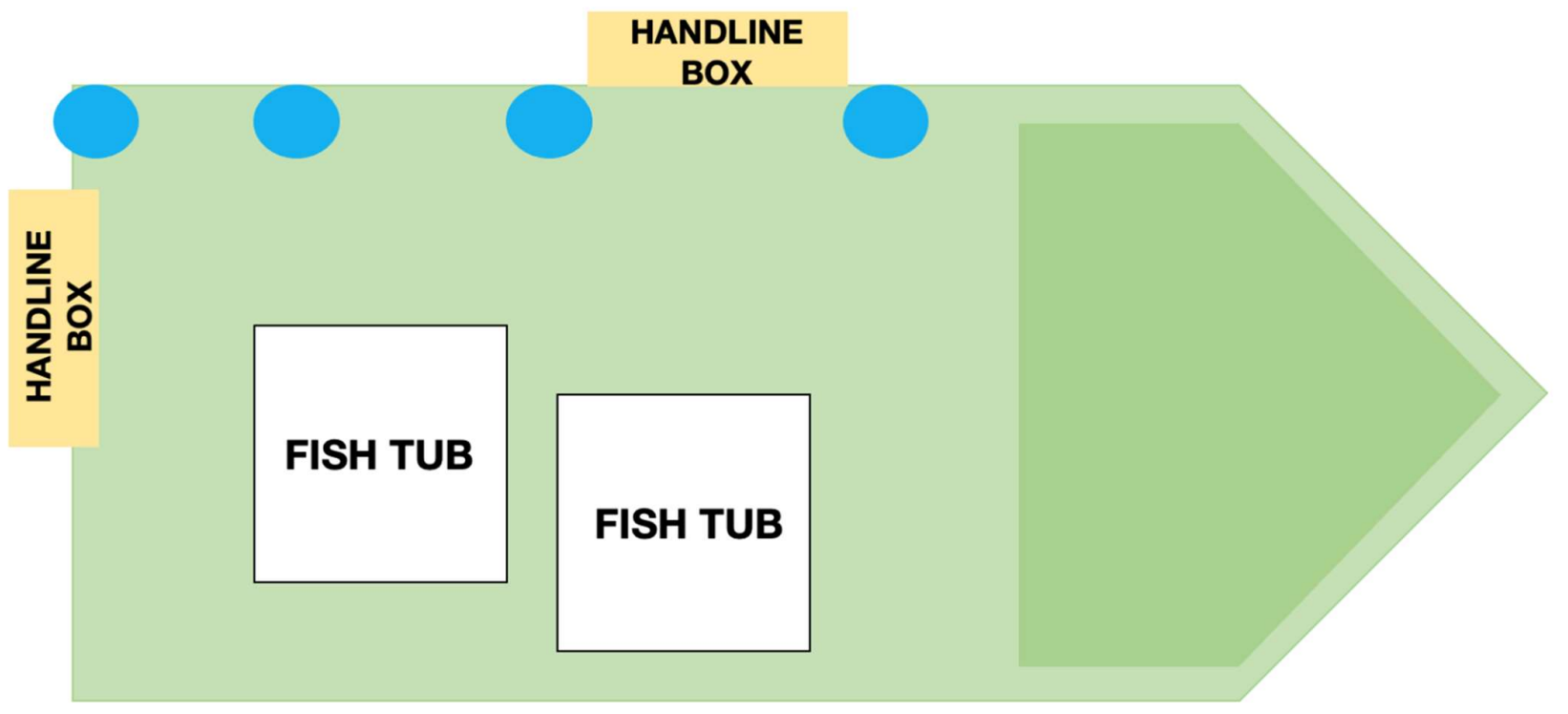

Figure 7. Structuring and arrangement of small boat, Individual no. 1.

The advantage of arrangement in Figure 7 is that there are two handline boxes onboard, however, there is a disadvantage since the handline box at the end of the boat is not optimally accessible. It would be more time efficient to move the handline box at the end of the boat to besides the other handline box on the side of the boat.

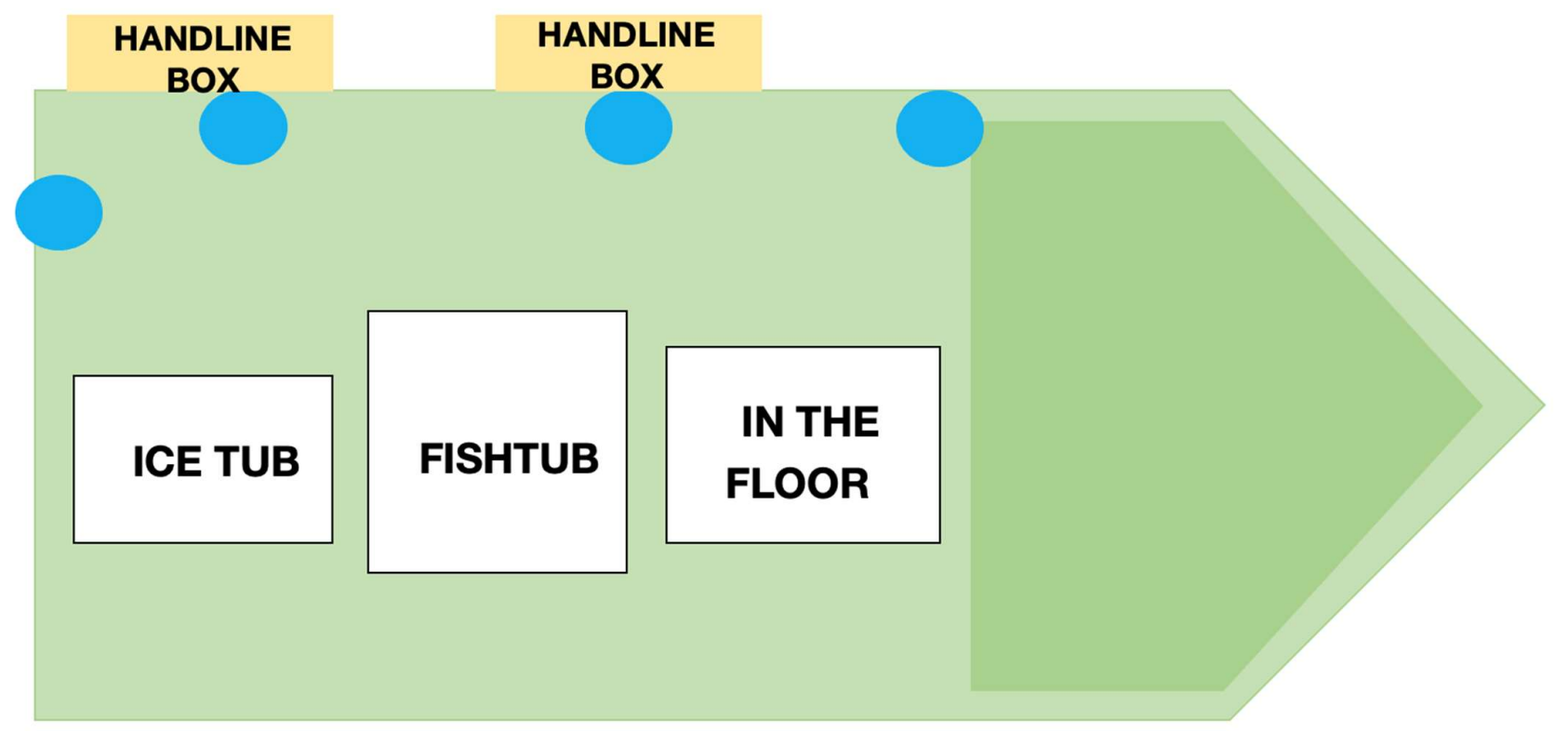

Figure 8. Structuring and arrangement of small boat, Individual no. 2.

The boat in Figure 8 has four automatic jigging machines and a separate tub with ice to cool the catch. Handline boxes are in a fair and accessible place, which means that the fish are much less likely to end up on the floor at some point, so it can be assumed that they are less likely to be affected by an impact during handling. 


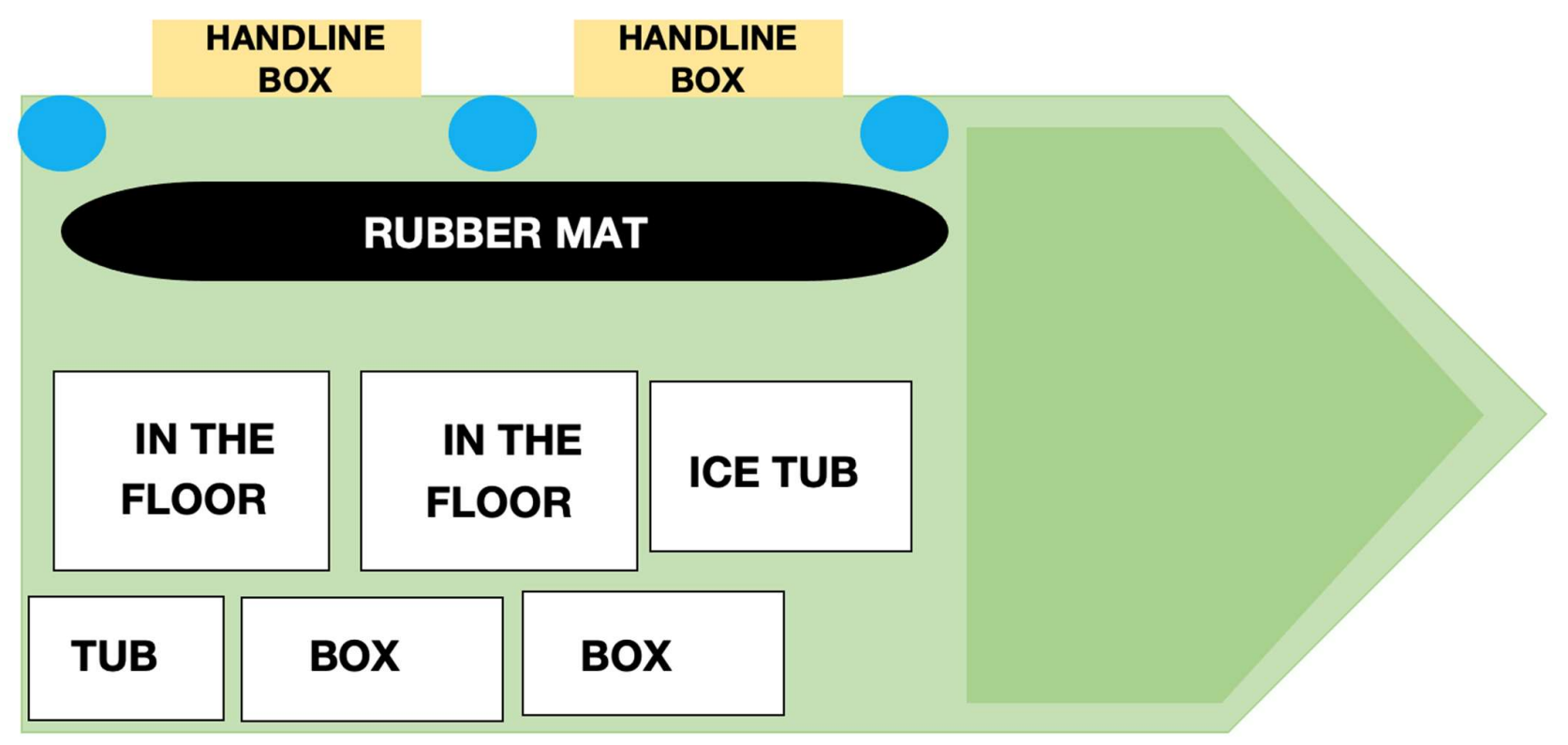

Figure 9. Structuring and arrangement of small boat, Individual no. 3.

The boat shown in Figure 9 can be considered to represent an exemplary spatial arrangement. There is a rubber mat on the floor, and handline boxes in an accessible place and a separate tub with ice. A person working on a boat that has storage for fish under the deck can be subjected to a great deal of physical strain when bending down to arrange the fish. The layout onboard this boat offers great potential for flow and minimise time inefficiencies. However, there is still potential for improvement, since a special bleeding and washing tub is missing, albeit remaining available space is limited.

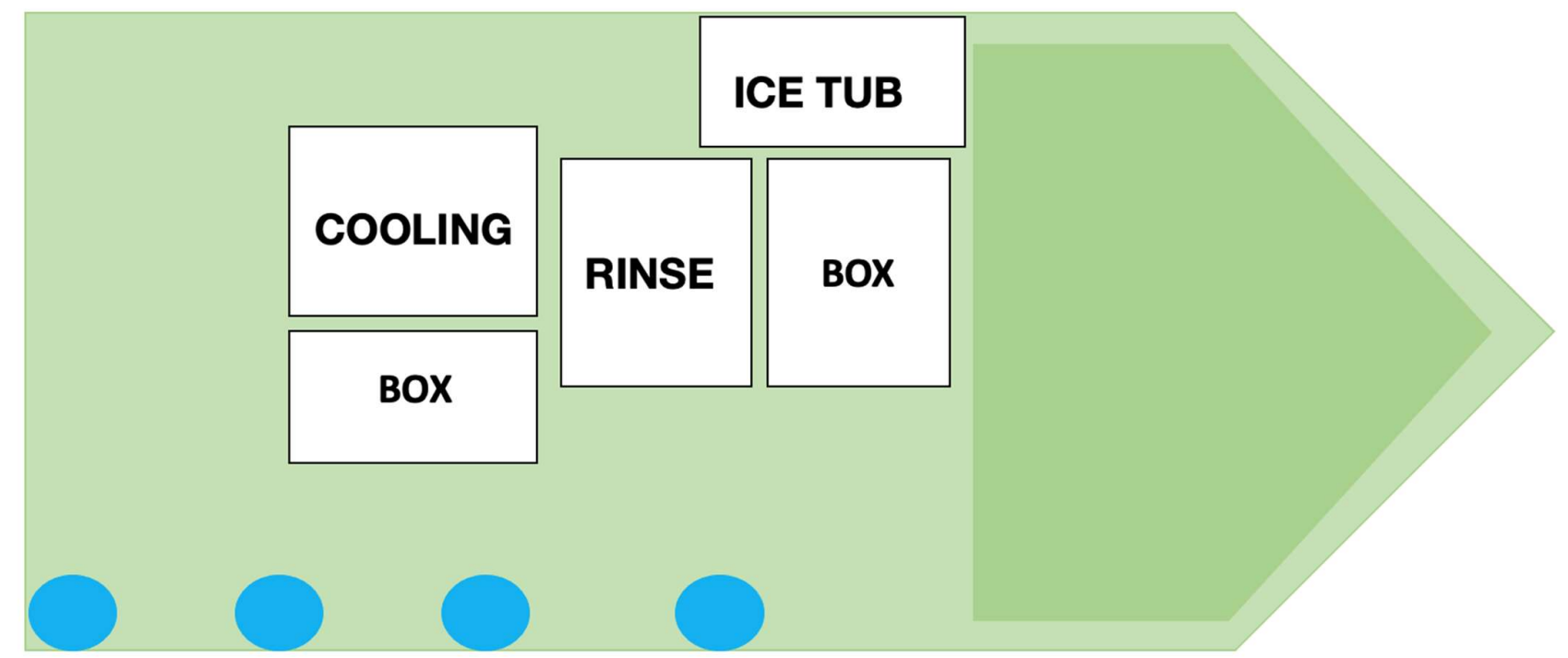

Figure 10. Structuring and arrangement of small boat, Individual no. 4. 
The boat shown in Figure 10 has certain advantages regarding the onboard arrangement, since there was a special tub in which the fish could bleed in a good flow of seawater. Ice was also stored in the shade, which means that the ice melted later than otherwise. Improvements could be secured in terms of storage. Hygiene was lacking, and fish were often stored in containers that were in the direct sun. There were also no handline boxes onboard, so the fish was either placed on the floor or thrown in the boxes marked as "Box" in bright red in Figure 10.

Based on the flow analysis of the respective boats, it is evident that there are considerable opportunities to improve flow on the small boats and boost efficiency. The thematic, value stream mapping and flow analysis make it possible to construct an exemplar template of flow of catch handling processes on a small boat. This is illustrated in Figure 11.

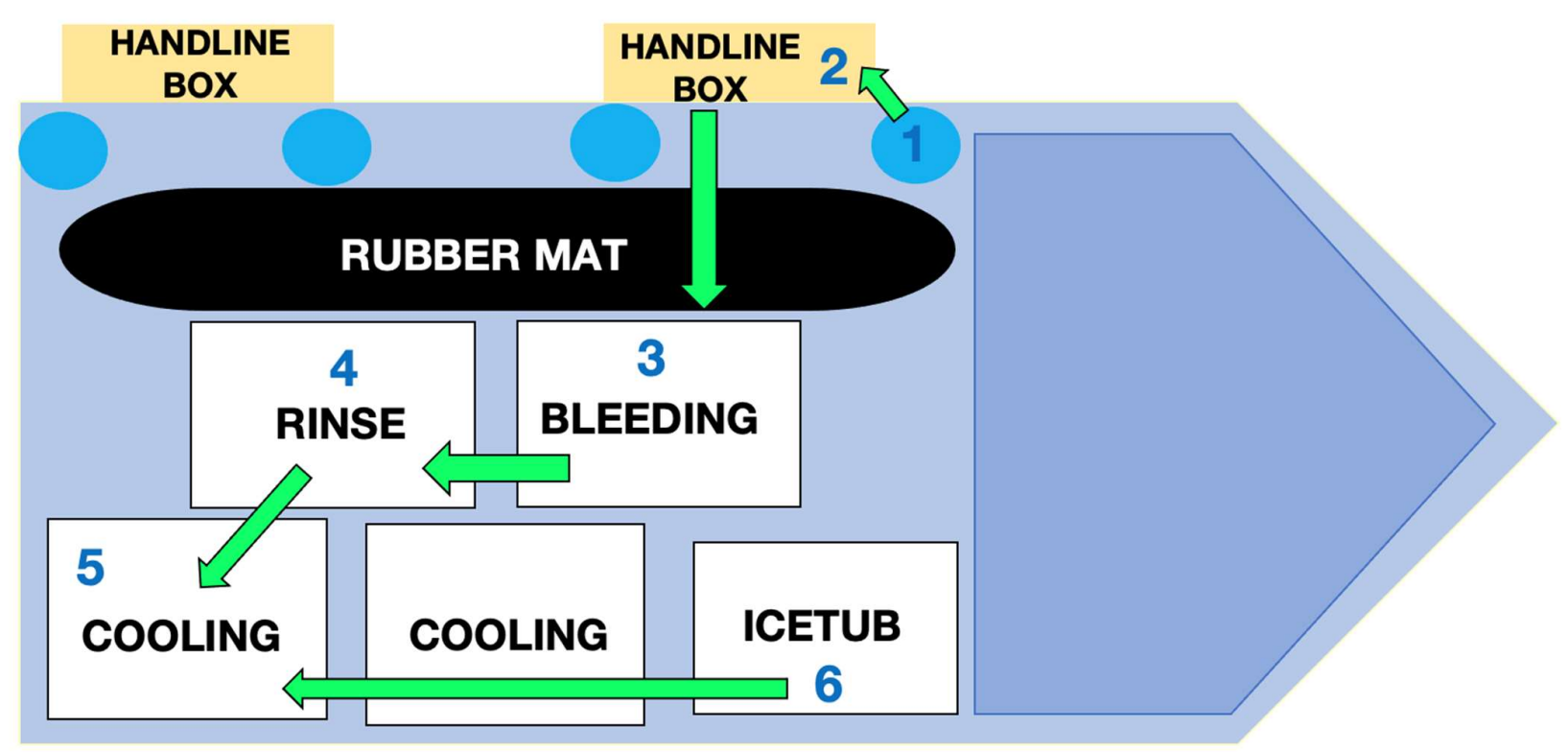

Figure 11. Exemplar flow in a boat with four automatic jigging machines.

Figure 11 includes four automatic jigging machines (the most common onboard format among Icelandic small boat fishers), denoted by the blue circles, and two handling boxes. The diagram assumes that there is storage room under the deck of the boat, or the fish is stored in fish tubs on the deck. The numbers and flow arrows denotes the stages in the process as follows: when the fish has reached the line on the automatic jigging machine (1); the fish is placed in the handline box (2); the hook is taken out and the fish is handled for bleeding, and, if time allows, water is showered box to cool the fish; the fish is placed in a bleeding tub (3); after the fish has been allowed to bleed out for 15-20 minutes, it is transferred to a washing tub (4); it is cleaned and then transferred into the cooling tub (5); and finally ice is added to the cooling tub (6).

4.1.4 Continuous improvement - Kaizen ideology and Priority Matrix

Kaizen ideology was applied through a 'five why's' process, which examined the root of five problems identified in the earlier stages, leading to enhancement measures that could lead to the exemplar onboard catch handling processes visualised in Figure 11. The five problems were those relating to safety, organisational arrangements, hygiene, fish handling and bleeding, and cooling. With respect to these, two main opportunities were identified - increasing organisation onboard and increasing onboard product traceability. Due 
to space constraints, the detailed Tables 4 to 11, which articulate the Kaizen idea forms, are included in this paper's Appendix A, where each problem is articulated with respect to the correction measure necessary to ensure exemplar onboard catch handling practices.

From the Kaizen idea forms, eight potential improvements to onboard catch handling practices were identified. These are as follows:

1. Increase safety onboard - in addition to standard safety equipment such as life vests, rubber mats should be included to reduce the risk of slippages.

2. Reduce unnecessary movement - ensure there are two handline boxes in an accessible place onboard.

3. Adopt First-in, First-Out (FIFO) method - the method assumes that the oldest stock is used first before the younger stock is used, i.e., first-in goes first-out [49]. The method is particularly suitable where fresh produce is being processed, and it is essential in which order the stocks are handled for bleeding or processed.

4. Improve hygiene - buckets are used to cool and clean the fish in the handline box, the deck and equipment are washed hourly with seawater, and before the start of the fishing trip, the deck is washed with soapy water.

5. Better bleeding - a bleeding tub is located onboard where the fish can bleed before being washed and put in an ice tub.

6. Enhance cooling - ensure there is enough ice to cool the catch onboard.

7. Optimise onboard organisation - increased flow onboard, with fishing gear and tools located efficiently and stored when not in use.

8. Increase traceability - wider use of webcams that can improve products' traceability and add value.

When it comes to reforming or improving a process, many modules construct that particular process, so it is important to prioritise those modules; the eight suggestions for improvements are prioritised according to difficulty level and possible impact using a Kaizen Priority Matrix (Figure 12).

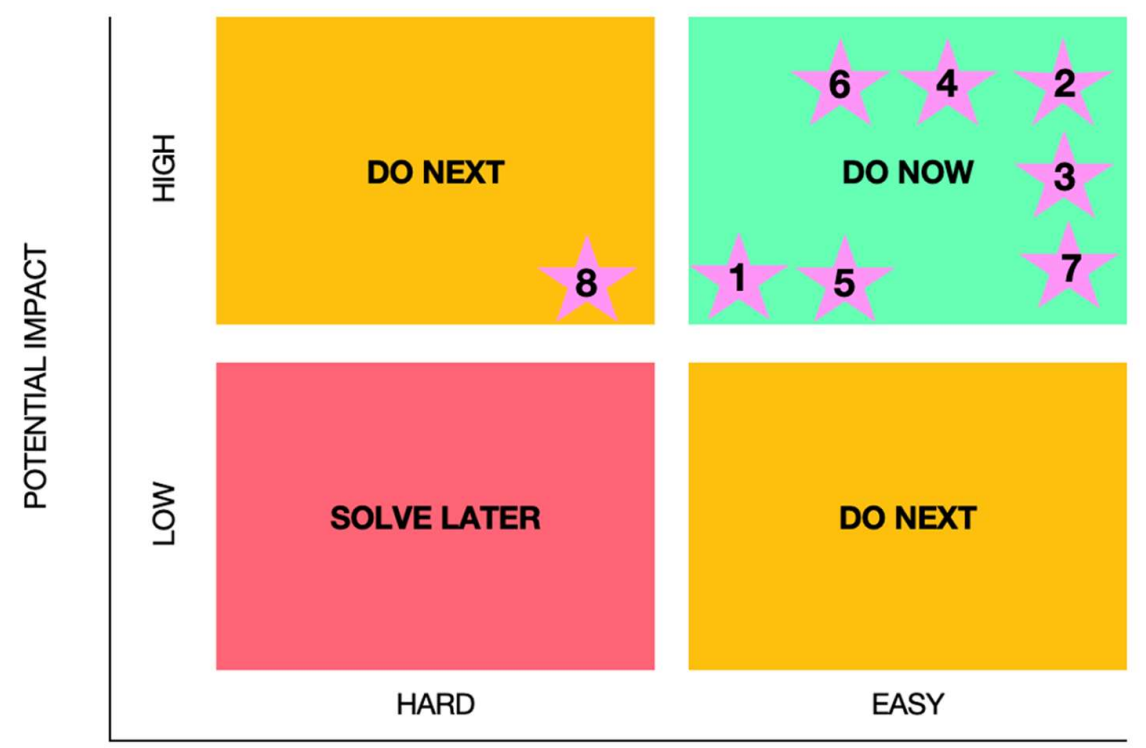

DIFFICULTY

Figure 12. Kaizen Priority matrix. 
When looked at the difficulty and potential impact these modules may have, it is evident that modules no. 1-7 are easy, low-cost improvements that are likely to have a a high impact. They are thus also classified under "Do now". The remaining module, no. 8, is classified as "Do next", since it relates not to an optimisation of process or quality management, but rather a market-value enhancing technique. However, adoption is still deemed to have high potential impact and medium difficulty.

4.2 Results from questionnaires

Analysis of the responses of the questionnaire participants is divided into the four main themes that emerged: the importance of small boat fishers, changes in recent decades, education and improvement, and the particularities of the sub-industry. In addition, this data is considered in the light of the potential contribution that efficiency and quality management enhancements by Icelandic small boat fishers could make towards compliance with the UN Sustainable Development Goals, as articulated in Table 1 of this paper.

\subsubsection{The importance of small boat fishers}

All respondents agreed that one of the main advantages of small boat fishing was the freshness of products. Respondent no. 1 voiced: "small boats bring the freshest fish ashore and thus ensure the most quality for processing and sale". Respondent no. 2 acknowledged the importance of sound onboard catch handling practices: "one must always be aware that they have a fresh product, a good but delicate product, which does not tolerate harmful or wrong handling". Respondent no. 3 reaffirmed the lack of standardisation of process found in the video analysis, voicing that "each one is responsible for his own".

When asked about the importance of small fishing boats in Iceland, Respondent no. 1 said they are essential for rural areas. He also stated that "small boat fishing ensures a diversity in the fishing industry, and in the event of a shock in the fishing industry, it is best not to have all the eggs in the same basket". According to Respondent no. 1, small boats are an environmentally friendly option given that "Small boats fish with stationary fishing gear and the fish, therefore, has a choice as to whether it bites or not. There is no environmental damage on the seabed". Therefore, in this respect, small boat fishers accord with the overarching objectives of UN SDGs 12 and 14 on responsible production, climate action, and minimising marine life disruption, respectively.

\subsubsection{Changes in recent decades}

Much has changed in the Icelandic fishing industry related to small boats in recent decades. Respondent no. 1 said that: "fishing on the largest boats now even exceeded 2000 tons, which was unknown a decade ago". Respondent no. 2 added that the quality of product is much higher today than it was 20-30 years ago. He specifically stated that access to ice is much better than it used to be back then. He also opined that "today, people are more aware of the importance of good work and handling of catches". Respondent no. 4 also added:

"The changes in fishing management for small boats have changed a lot in their favour. The boats are much better than before and in most cases, people know what they can do, both in the hook catch system and the coastal fishing and can therefore organise themselves better".

When asked about changes in small boats' external environment, Respondent no. 1 said:

"Coastal fishing was established in 2009. Cod catch per fishing trip is limited at $774 \mathrm{~kg}$ of ungutted fish, which gives more time to clean up properly. Larger boats have joined their fleet, and the number of the crew has grown from 2 to 4 ". 
With the advent of the fourth industrial revolution and other changes brought about by technology, many things have changed in recent decades. The utilisation of fish has changed, and small boats have become better than before. With increased knowledge of the fish resource and technology, small boat fishing has become more efficient and yields higher quality than 20-30 years ago. In this context, technological improvements are a form of innovation and infrastructure development, supporting UN SDG 9.

The importance of good catch handling was deemed by the respondents to be key to a good end-product. Respondents affirmed that the freshness of the catch caught on small boats is the specialty of the Icelandic small boat fisher, and the consumer trusts that the fish is well cared for to maintain its quality. The consumer also trusts that every actor in the supply chain from fishing to cooking will do their utmost to ensure that the final product is of the highest quality, supporting the pursuit of UN SDG 12. Small-boat fishing involves minimal or zero damage to the seabed and is more environmentally sustainable than other forms of fishing in Iceland, since oil consumption is kept to a minimum. It thus supports UN SDGs 13 and 14, which focus on minimising climate change impacts and marine life disruption.

\subsubsection{Education and improvement}

Education and constant reminders were viewed to be an effective way to maintain good catch handling practices. "Education on catch management and constant propaganda to fishermen thus builds ambition to succeed. At the same time, mobilising everyone for supervision" is quoted by Respondent no. 1. Respondent no. 2 added that:

"It is important that people share their experience with those who are new to the job. It is in everyone's interest to create an excellent overall framework for fishing so that people can stand upright and be proud of their contribution to the fisheries industry and their work."

When asked what could be improved, Respondent no. 4 was vague and said there is always room for improvement. Respondent 1 was more precise, contributing that there were "no direct problems, [but that] one of the main things is that too much is fished in each voyage on the line," and that handline fishing can always be improved. He added that Icelandic small boat fishers should:

"Always be vigilant about what can be done better and have enough ice to cool the catch. It is essential to be on guard and not exceed the amount of catch that can be cooled and arranged into fish tubs."

Respondent 3 said that what could be improved onboard were hygiene requirements: “The Directorate of Fisheries' supervision is very extensive, but they could perhaps set out to improve hygiene". It was not clear whether the respondent was demanding formal regulations to ensure this occurred, or alternatively simple guidance on best practice approaches to onboard hygiene. Regardless of the form, it is evident that through increased education and knowledge, it is possible to maintain and improve the efficiency of catch management. In so doing, Icelandic small boat fishers provide a supportive contribution to UN SDG 4.

\subsubsection{Particularities of the sub-industry}

When asked about the fishing itself, Respondent no. 4 said that "most of the boats are relatively narrow, so it is difficult to have a sludge system onboard, but that should result in the best cooling". He also stated that: 
"Coastal fishing is practiced in the summer when the sea temperature is higher than in other seasons, and the weather is warmer.

The fish are more sensitive, so rapid bleeding and cooling are essential to maintain value and quality."

Respondent no. 2 talked about a race against time: "It's crucial continuing to bring the catch as chilled and fresh ashore as possible. It sounds simple, but it's racing against time". He also said that it was impossible to work on a boat and be connected to a lifeline. On the issue of safety, he also talked about the dangers of an industry where people go out to sea alone.

When asked if there is anything that can be done to protect the quality and value of catches caught on small boats, Respondent no. 4 said:

"It is first and foremost adequate cooling, but buyers in fish markets must make sure not to pay too high a price for poor quality

fish and allow them to enjoy those who do well".

Respondent no. 2 added that "fish must always be handled for bleeding as soon as possible, then left in a fresh flow of sea for a while so that the fish bleeds out properly". This respondent also came up with the idea of a certificate of origin relating to onboard web cameras, which could film and verify catch handling processes in real-time, something that chimed with the outcomes from the video analysis part of this paper.

To maintain the fish's quality, careful consideration must be given to bleeding and handling the catch as soon as the fish has reached the surface. When handling fresh produce, hygiene, and all the small factors that affect the final product must be considered. The abovementioned indicates responsible production that supports UN SDG 12.

\section{Discussion and conclusion}

5.1 Summary of main findings

This paper set out to explore whether standardisation of operations can be applied to make catch management on small boats more efficient in Iceland. Applied research methods were adopted to investigate the practical nature of the issue, discovering problems and process enhancement opportunities in onboard catch handling practices. Kaizen ideology and a related priority matrix were development, from which eight core recommendations were formed, practices that if standardised by Icelandic small boat fishers using automatic jigging machines would lead to efficiency gains, linked to time and resources, and improved quality management. In turn, these would lead to economic efficiency improvements and the sub-industry would provide further ballast to several of the UN's SDGs and their respective targets. The recommendations for exemplar practice include issues relating to safety, ergonomic aspects, hygiene, bleeding, cooling, and traceability, none of which alone is likely to make a significant difference to the economic success of the venture, however, combined adoption could potentially lead to significant benefits for small boat fishers.

5.2 Constraining factors and concerns

The technical issues and recommendations for standardisation based on exemplar performance criteria are bound by the usual constraints faced by any operator. They include, but are not limited to, available credit or financial resources, time constraints as applicable in any technical restructuring or updating, available material resources for those technical updates, and a practicable method of introducing and implementing those updates. As far as the human side of change is concerned, the situation is complex. 
The owners and workers' education on these vessels will likely become more critical in the future, as globalised societies undertake the digital transition, introducing more electronic processing equipment, quality control, and monitoring. Additionally, the vessels themselves will most likely change as well as demands for environmentally friendlier methods, especially fuel consumption, become more stringent.

Another field of concern on these small boats is the personal safety of the crew. Accidents and loss of life have been prevalent throughout the history of Icelandic fishing, but through training and vastly improved communications systems and rescue equipment, loss of life has been reduced to almost zero. In the video analysis it was evident that in most cases, security lines are not used. Despite this, a very low accident rate in Icelandic coastal fisheries was reported in the interviews and the recent study by Gunnlaugsson et al. [17], however, the authors also reported that minor incidents, mostly caused by mechanical failure, were very frequent in the coastal fisheries compared to other Icelandic fisheries. .

A future expansion in Icelandic small-scale fisheries is a possibility, with arguments in the academic literature for the increased use of these smaller vessels compared to traditional trawling methods, due to perceived advantages in terms of the quality of the product, timely landing process, much lower upfront investment costs, and efficient delivery to major markets [19]. Chambers et al. [15] found evidence that small-scale fisheries contribute incalculably to cultural identity, sense of place and pride, physical and emotional wellbeing, and food security. In contrast, there are voices in the Icelandic industry that the small-scale industry remains economically inefficient compared to industrial-scale fishing [17] and its existence is unfair given the many years of conservation efforts by fishers for the most sought-after fish stocks.

5.3 Limitations and validity of the study

The study assumed that standardisation of process according to exemplar standards will lead to more efficient onboard better catch management onboard, and ultimately a product of consistently higher quality. This ignores the human element of the study, whereby recommendations for improvement may lead to superior rules and processes, but it depends greatly on the individual fisher whether he/she uses the knowledge and the tools in front of him/her. The outcomes from the Kaizen ideology process and the questionnaires affirmed that it is the human factor that is most responsible for poor catch management. Ultimately, when the catch is often not handled in accordance with best practice, this may often be simply due to the fishers' pressures of time rather than an absence of knowledge about optimal procedures. Additionally, regardless of the potential benefits, standardisation of practice across an industry always demands adaptability and can be met with age-old resistance to change. Partly, this may relate to trust issues when regulations are imposed on remote communities by national governance agencies. The survey of Icelandic small boat fishermen by Chambers \& Carruthers [10] revealed considerable mistrust of government agencies concerning Individual Transferable Quotas that were imposed with the perception of little or no local consultation. Finally, it is also important to note that many of the 'do now' measures determined by the Kaizen Priority Matrix will require more training and economic investment on the part of fishers, which may present a constraining factor.

The methods used were considered suitable for this study. However, it is acknowledged that the COVID-19 virus also impacted the design of this study, as it has numerous other social science inquiries around the world. A deepening of insights would likely have been attained through the deployment of in-person, semi-structured interviews, as well as opportunities to observe and record practices onboard in addition to secondary data secured from videos.

In addition, it would have been useful if more than four videos had been available to review on board processing activities, including operations involving more than one crew member. This study's findings were based on a relatively small sample of videos and 
questionnaire responses. Although the latter echoed greatly with the former, the data may still be insufficient to form recommendations that are specific to all Icelandic small boat fishers using automatic jigging machines. Indeed, the participants in this study constitute only a fraction of the participants who engage in small boat fishing in Iceland.

\subsection{Conclusion}

In recent years, the Icelandic marine sector has become renowned for its economic efficiency, innovating successfully to develop new products, eliminating waste and contributing to the simultaneous pursuit of multiple sustainability objectives. Icelandic small boat fishers constitute a small sub-sector but have been critical to sustaining the economic prosperity of remote communities with few options for economic diversification. However, to date, no research had been conducted on opportunities within Icelandic small boat fishing to enhance the efficiency of the processes between catch and landing of catch.

This study's two phases of qualitative analysis revealed considerable variability in working methods and opportunities for the standardisation of catch handling practices to deliver efficiency enhancement, both time and resource-related. Thematic analysis, value stream mapping, flow analysis and Kaizen ideology were applied sequentially in order to identify gaps in best practice and opportunities to transition to exemplar standards. A total of eight recommendations were outlined, comprised of a mixture of human and technological interventions targeting four areas central to exemplar catch handling: bleeding, gutting, good washing, and cooling. Ergonomic improvements relating to the spatial arrangement of tools and equipment onboard may be the easiest and most practical recommendations for small boat fishers to adopt, and of least cost. Boxes, ice buckets, saltwater containers, and possibly a cooling system operated by reactive chemicals, are some of the issues that need to be considered. Through enhanced efficiency of onboard catch handling processes, small boat fishers in Iceland can support the pursuit of several of the UN's SDGs, including those relating to education (SDG 4), innovation (SDG 9), responsible production (SDG 12), climate action (SDG 13), and life below water (SDG 14).

Several options emerge for future research. Firstly, once the COVID-19 virus abates, it is recommended that onboard practices are studies more deeply through in-person observations on Icelandic small boats. Secondly, there is now a need for a quantitative assessment, examining the extent to which the adoption of the recommendations in this paper leads to cost-savings and increased profits. Thirdly, greater consideration needs to be given to exactly how the recommendations advanced in this paper are adopted in practice - should a voluntary code of practice be developed or is more formal government-led regulation necessary? Fourthly, it would be beneficial to conduct focus groups with stakeholders, especially the small boat fishers themselves, to ascertain their attitudes and likely responses to the recommendations.

\section{Acknowledgements}

This paper has been funded by The Icelandic Student Innovation Fund by the Icelandic Centre for Research (grant number 2075690091), Íslandsbanki and NordForsk (grant number 76654) via their financial support to the Nordic Centre of Excellence ARCPATH (Arctic Climate Predictions - Pathways to Resilient, Sustainable Communities).

\section{Conflicts of Interest}

The authors declare no conflict of interest. The funders had no role in the design of the study; in the collection, analyses, or interpretation of data; in the writing of the manuscript, or in the decision to publish the results.

\section{Author Contributions}

Conceptualization, Ingibjörg Karlsdóttir; Data curation, Ingibjörg Karlsdóttir; Funding acquisition, Ingibjörg Karlsdóttir; Investigation, Ingibjörg Karlsdóttir; Methodology, Ingibjörg Karlsdóttir and Inga Minelgaité; Project administration, David Cook and Inga 
Minelgaité; Resources, Inga Minelgaité; Supervision, David Cook and Inga Minelgaité; Validation, David Cook; Visualization, Inga Minelgaité; Writing - original draft, David Cook; Writing - review \& editing, David Cook and Inga Minelgaité.

\section{Appendix A}

Table A4. Kaizen idea form, Issue no. 1. 


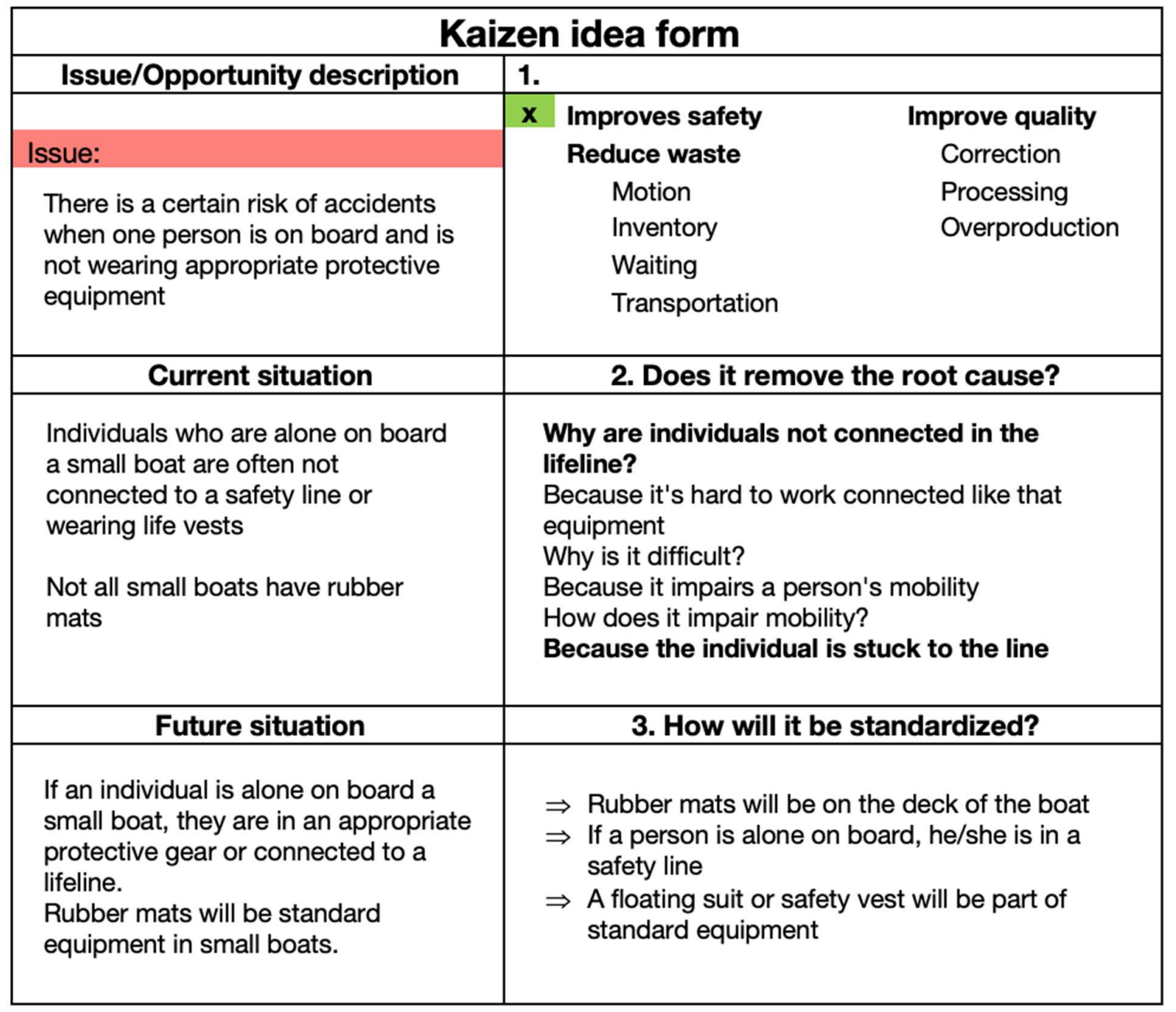

Table A5. Kaizen idea form, Issue no. 2. 


\begin{tabular}{|c|c|c|}
\hline \multicolumn{3}{|c|}{ Kaizen idea form } \\
\hline \multirow[t]{2}{*}{ Issue/Opportunity description } & \multicolumn{2}{|l|}{1.} \\
\hline & Improves safety & \multirow{6}{*}{$\begin{array}{l}\text { Improve quality } \\
\text { Correction } \\
\text { Processing } \\
\text { Overproduction }\end{array}$} \\
\hline Issue: & X Reduce waste & \\
\hline \multirow{4}{*}{$\begin{array}{l}\text { High speed characterizes small boat } \\
\text { fishing, but a poor organization can } \\
\text { increase a certain amount of waste } \\
\text { in the process }\end{array}$} & x Motion & \\
\hline & Inventory & \\
\hline & x Waiting & \\
\hline & x Transportation & \\
\hline Current situation & \multicolumn{2}{|c|}{ 2. Does it remove the root cause? } \\
\hline $\begin{array}{l}\text { Certain irregularities can occur } \\
\text { onboard, but a lot of waste can } \\
\text { arise in terms of excess movement, } \\
\text { waiting, and transport of fish. }\end{array}$ & \multicolumn{2}{|c|}{$\begin{array}{l}\text { Why is there waste, such as unnecessary } \\
\text { movement, waiting, and transportation? } \\
\text { Because high speed characterizes small boat fishing } \\
\text { Why? Because the fish are being pulled up at high } \\
\text { speed and need to be released from the line as soon } \\
\text { as possible. } \\
\text { Why? So that the fish do not escape from the hook } \\
\text { on the line. } \\
\text { How do is it made sure that the fish do not escape? } \\
\text { They are picked up very quickly into the boat and } \\
\text { often placed on the floor of the vessel } \\
\text { Why are they placed on the floor? } \\
\text { Because handline boxes are often insufficient or } \\
\text { inaccessible }\end{array}$} \\
\hline Future situation & \multicolumn{2}{|c|}{ 3. How will it be standardized? } \\
\hline $\begin{array}{l}\text { At least two handline boxes are on board } \\
\text { and are in an accessible place, i.e. both } \\
\text { on the same edge of the boat. If there are } \\
\text { three automatic jigging machines, there } \\
\text { are two boxes on each side of the jigging } \\
\text { machine in the middle. } \\
\text { If there are four jigging machines, then } \\
\text { box no. } 1 \text { is located between machines } 1 \\
\text { and } 2 \text {, box no. } 2 \text { is then located between } \\
\text { machines } 3 \text { and } 4 . \\
\text { The FIFO method is used. } \\
\text { For example: if there are three fish in } \\
\text { handline box no. } 1 \text { and then three other } \\
\text { fish bite on the line, they are taken and } \\
\text { placed in handline box no. } 2 \text {. First, the } \\
\text { fish in handline box } 1 \text { (first-in) are } \\
\text { handled for bleeding and put into a fish } \\
\text { tub (first-out), and then fish in handline } \\
\text { box } 2 \text { are handled for bleeding. }\end{array}$ & \multicolumn{2}{|c|}{$\begin{array}{l}\text { Movement: } \\
\text { There are enough gearboxes on board. Therefore, } \\
\text { freshly caught fish can be stored in a suitable } \\
\text { place and not on the floor, so the individual does } \\
\text { not have to bend over to pick up the fish from the } \\
\text { floor. } \\
\text { Waiting: } \\
\text { The FIFO (first-in, first-out) method must be used } \\
\text { when arranging fish in fish tubs. Sufficient } \\
\text { handline boxes are needed for FIFO to work. } \\
\text { Transportation: } \\
\text { Handline boxes are in an accessible place. It can } \\
\text { solve the problem that an individual puts fish on } \\
\text { the floor and then has to move the fish closer to } \\
\text { the handline box where the knives are often } \\
\text { stored. }\end{array}$} \\
\hline
\end{tabular}

Table A6. Kaizen idea form, Issue no. 3. 


\begin{tabular}{|c|c|c|}
\hline \multicolumn{3}{|c|}{ Kaizen idea form } \\
\hline \multirow{2}{*}{ Issue/Opportunity description } & \multicolumn{2}{|l|}{1.} \\
\hline & Improves safety & x Improve quality \\
\hline Issue: & Reduce waste & Correction \\
\hline \multirow{4}{*}{$\begin{array}{l}\text { Hygiene is often lacking on small } \\
\text { boats, both on board the boat and } \\
\text { when it comes to the catch } \\
\text { treatment itself. }\end{array}$} & Motion & $x$ Processing \\
\hline & Inventory & Overproduction \\
\hline & Waiting & \\
\hline & Transportation & \\
\hline Current situation & \multicolumn{2}{|c|}{ 2. Does it remove the root cause? } \\
\hline $\begin{array}{l}\text { Those who work on small boats } \\
\text { know how important hygiene is } \\
\text { when it comes to catch treatment, } \\
\text { but there is always room for } \\
\text { improvement. }\end{array}$ & \multicolumn{2}{|c|}{$\begin{array}{l}\text { Hygiene is often lacking in small boats } \\
\text { Why? Because often the boat itself and the catch } \\
\text { is not rinsed well enough } \\
\text { Why? There are no special regulations on } \\
\text { hygiene } \\
\text { Why? Because everyone is trusted to do } \\
\text { everything they can when it comes to hygiene }\end{array}$} \\
\hline Future situation & \multicolumn{2}{|c|}{ 3. How will it be standardized? } \\
\hline $\begin{array}{l}\text { A rope is used to pull up buckets } \\
\text { with fresh seawater that can be } \\
\text { used to rinse freshly bled fish in a } \\
\text { handline box. } \\
\text { The deck is much cleaner as it is } \\
\text { rinsed with soapy water before } \\
\text { every fishing trip as well as being } \\
\text { washed regularly with fresh } \\
\text { seawater. } \\
\text { When the fish is rinsed well, there is } \\
\text { less chance of bacterial damage. }\end{array}$ & \multicolumn{2}{|c|}{$\begin{array}{l}\Rightarrow \text { A bucket is used to shower seawater into the } \\
\text { handline box while the fish is freshly caught and } \\
\text { bled, it both cleans the fish and cools it, as well } \\
\text { as washes away dirt that can accumulate in the } \\
\text { box - a small hole must be at the bottom of the } \\
\text { side on the box so the sea can get out of the } \\
\text { box } \\
\Rightarrow \text { Every hour or while there is spare time, the deck } \\
\text { is washed with fresh seawater } \\
\Rightarrow \text { Before every fishing trip, the deck is rinsed with } \\
\text { soapy water }\end{array}$} \\
\hline
\end{tabular}

Table A7. Kaizen idea form, Issue no. 4. 


\begin{tabular}{|c|c|c|}
\hline \multicolumn{3}{|c|}{ Kaizen idea form } \\
\hline \multirow[t]{2}{*}{ Issue/Opportunity description } & \multicolumn{2}{|l|}{1.} \\
\hline & \multirow{6}{*}{$\begin{array}{l}\text { Improves safety } \\
\text { Reduce waste } \\
\text { Motion } \\
\text { Inventory } \\
\text { Waiting } \\
\text { Transportation }\end{array}$} & Improve quality \\
\hline Issue: & & Correction \\
\hline \multirow{4}{*}{$\begin{array}{l}\text { It is possible to do better when } \\
\text { handling fish for bleeding }\end{array}$} & & x Processing \\
\hline & & Overproduction \\
\hline & & \\
\hline & & \\
\hline Current situation & \multicolumn{2}{|c|}{ 2. Does it remove the root cause? } \\
\hline $\begin{array}{l}\text { Often, the bleeding of fish is not } \\
\text { done well enough. When a fish is } \\
\text { well bled, its flesh is white, but when } \\
\text { a fish is badly bled, there is still } \\
\text { blood left in the flesh. }\end{array}$ & \multicolumn{2}{|c|}{$\begin{array}{l}\text { Blood is still left in the flesh of the fish } \\
\text { Why? Because the fish have not been allowed to } \\
\text { bleed long enough and well } \\
\text { Why? Because there is not enough circulation on } \\
\text { the water } \\
\text { Why? Because there is not always a separate } \\
\text { bleeding tub on board where the fish is allowed to } \\
\text { bleed in fresh running water for } 15-20 \text { minutes } \\
\text { before being washed }\end{array}$} \\
\hline Future situation & \multicolumn{2}{|c|}{ 3. How will it be standardized? } \\
\hline $\begin{array}{l}\text { The fish bleeds in fresh running } \\
\text { seawater for } 15-20 \text { minutes before } \\
\text { being placed in a washing tub, then } \\
\text { into an ice tub. }\end{array}$ & \multicolumn{2}{|c|}{$\begin{array}{l}\Rightarrow \text { A special bleeding tub is located onboard } \\
\text { where the fish is allowed to bleed for } 15-20 \\
\text { minutes before being washed and placed in } \\
\text { an ice tub }\end{array}$} \\
\hline
\end{tabular}

Table A8. Kaizen idea form, Issue no. 5. 


\begin{tabular}{|c|c|c|c|}
\hline \multicolumn{4}{|c|}{ Kaizen idea form } \\
\hline \multirow[t]{2}{*}{ Issue/Opportunity description } & \multicolumn{3}{|l|}{1.} \\
\hline & \multirow{6}{*}{$\begin{array}{l}\text { Improves safety } \\
\text { Reduce waste } \\
\text { Motion } \\
\text { Inventory } \\
\text { Waiting } \\
\text { Transportation }\end{array}$} & X Im & prove quality \\
\hline Issue: & & & Correction \\
\hline \multirow{4}{*}{$\begin{array}{l}\text { The cooling of the catch is not } \\
\text { always done well enough }\end{array}$} & & $x$ & Processing \\
\hline & & & Overproduction \\
\hline & & & \\
\hline & & & \\
\hline Current situation & \multicolumn{3}{|c|}{ 2. Does it remove the root cause? } \\
\hline $\begin{array}{l}\text { Cooling slows down the damage } \\
\text { caused by bacteria. In order for fish } \\
\text { to maintain their quality for as long } \\
\text { as possible, it is necessary to pay } \\
\text { close attention to the cooling of the } \\
\text { catch onboard. }\end{array}$ & \multicolumn{3}{|c|}{$\begin{array}{l}\text { The cooling of the catch is not done well } \\
\text { enough } \\
\text { Why? Because there is not always enough ice on } \\
\text { board } \\
\text { Why? The temperature of the sea depends on the } \\
\text { time of year and therefore requires different } \\
\text { amounts of ice } \\
\text { Why isn't the amount of ice assumed depending on } \\
\text { what season it is? } \\
\text { The amount of catch is often in excess of what } \\
\text { can be cooled }\end{array}$} \\
\hline Future situation & \multicolumn{3}{|c|}{ 3. How will it be standardized? } \\
\hline $\begin{array}{l}\text { The amount of ice is calculated } \\
\text { before each trip, as well as the } \\
\text { amount of catch that can be cooled. } \\
\text { lce must be provided to maintain } \\
\text { the cooling until the fishing trip is } \\
\text { over. }\end{array}$ & \multicolumn{3}{|c|}{$\begin{array}{l}\Rightarrow \text { Use the ice-app from Matís to calculate the } \\
\text { ice requirement for each trip } \\
\Rightarrow \text { A bigger ice tub is better than a small one } \\
\Rightarrow \text { Calculate the amount of catch that can be } \\
\text { cooled, and not exceed that amount }\end{array}$} \\
\hline
\end{tabular}

Table A9. Kaizen idea form, Opportunity no. 1. 


\begin{tabular}{|c|c|c|c|}
\hline \multicolumn{4}{|c|}{ Kaizen idea form } \\
\hline \multirow[t]{2}{*}{ Issue/Opportunity description } & \multicolumn{3}{|l|}{1.} \\
\hline & \multicolumn{2}{|r|}{ Improves safety } & Improve quality \\
\hline \multirow{5}{*}{$\begin{array}{l}\text { Opportunity: } \\
\text { Increased organization onboard }\end{array}$} & $\mathbf{x}$ & Reduce waste & Correction \\
\hline & & $\mathrm{x}$ Motion & Processing \\
\hline & & Inventory & Overproduction \\
\hline & & Waiting & \\
\hline & & Transportation & \\
\hline Current situation & \multicolumn{3}{|c|}{ 2. Does it remove the root cause? } \\
\hline $\begin{array}{l}\text { Not all small boats have a special } \\
\text { storage place for beaks or knives, } \\
\text { but there are items that are widely } \\
\text { used onboard. It can be time- } \\
\text { consuming to look for a knife that is } \\
\text { located on the bottom of a handline } \\
\text { box that is packed with fish. }\end{array}$ & \multicolumn{3}{|c|}{$\begin{array}{l}\text { It saves time when tools have their place on } \\
\text { board } \\
\text { Why? Because all crew members know where } \\
\text { each tool is at any given time } \\
\text { Why? This makes it easier to access the tools } \\
\text { needed for each operation } \\
\text { Why? Because an individual does not have to } \\
\text { look for the tool and reduces the waste } \\
\text { associated with movement }\end{array}$} \\
\hline Future situation & \multicolumn{3}{|c|}{ 3. How will it be standardized? } \\
\hline $\begin{array}{l}\text { Knives are in a knife rack and } \\
\text { fastened to a string so that it does } \\
\text { not fall overboard. } \\
\text { The beak has a special place next to } \\
\text { the jigging machine where it is easy } \\
\text { to reach. }\end{array}$ & \multicolumn{3}{|c|}{$\begin{array}{l}\Rightarrow \text { A knife is attached to a string so that it never } \\
\text { goes overboard and has a special } \\
\text { compartment or a stand so that the knife can } \\
\text { be inserted when not in use } \\
\Rightarrow \text { The beak has a special place next to the } \\
\text { handline box or jigging machine in which the } \\
\text { shaft can be slid into }\end{array}$} \\
\hline
\end{tabular}

Table A10. Kaizen idea form, Opportunity no. 2. 


\begin{tabular}{|c|c|c|}
\hline \multicolumn{3}{|c|}{ Kaizen idea form } \\
\hline \multirow[t]{2}{*}{ Issue/Opportunity description } & \multicolumn{2}{|l|}{1.} \\
\hline & Improves safety & x Improve quality \\
\hline Opportunity: & Reduce waste & Correction \\
\hline \multirow{4}{*}{$\begin{array}{l}\text { Increased product traceability } \\
\text { caught on small boats. }\end{array}$} & Motion & $x$ Processing \\
\hline & Inventory & Overproduction \\
\hline & Waiting & \\
\hline & Transportation & \\
\hline Current situation & \multicolumn{2}{|c|}{ 2. Does it remove the root cause? } \\
\hline $\begin{array}{l}\text { Fish tubs are marked with the name } \\
\text { of a boat, and in this way, it is } \\
\text { possible to identify the origin of the } \\
\text { product, but it does not indicate } \\
\text { whether the catch treatment was } \\
\text { carried out correctly. }\end{array}$ & \multicolumn{2}{|c|}{$\begin{array}{l}\text { The traceability of products caught on small } \\
\text { boats could be improved with a webcam } \\
\text { Why? Because then the buyer can monitor the } \\
\text { fishing } \\
\text { Why is it preferable? So that the buyer of fish } \\
\text { from a particular boat can then see how the catch } \\
\text { treatment is carried out } \\
\text { Why? Consumers are very aware and want to } \\
\text { know about the origin of the product. This } \\
\text { could increase the value of the fish if the catch } \\
\text { treatment is done well }\end{array}$} \\
\hline Future situation & \multicolumn{2}{|c|}{ 3. How will it be standardized? } \\
\hline $\begin{array}{l}\text { Increased traceability of marine } \\
\text { products caught on small boats with } \\
\text { the advent of webcams. }\end{array}$ & \multicolumn{2}{|c|}{$\begin{array}{l}\Rightarrow \text { Use of webcams attached to the boat and } \\
\text { monitor the fishing as it takes place. } \\
\text { Individuals who are interested in buying fish } \\
\text { from this particular boat can therefore follow } \\
\text { the fishing and be sure that the catch } \\
\text { treatment is done correctly }\end{array}$} \\
\hline
\end{tabular}


1. Gunnlaugsson, S. B., Saevaldsson, H., Kristofersson, D. M., \& Agnarsson, S. (2020). Resource Rent and its Distribution in Iceland's Fisheries. Marine Resource Economics, 35(2), 000-000.

2. FAO (Food and Agriculture Organization of the United Nations). 2017. "Global Capture Production 1950- 2016." www.fao.org/fishery/statistics/global-capture-production/query/en.

3. Arnason, R. (2009). Conflicting uses of marine resources: can ITQs promote an efficient solution?. Australian Journal of Agricultural and Resource Economics, 53(1), 145-174.

4. Byrne, C., Agnarsson, S., \& Davidsdottir, B. (2019). Profit and rent in the Icelandic harvesting sector. Fisheries Research, 220, 105349.

5. Byrne, C., Agnarsson, S., Davidsdottir, B., \& Oostdijk, M. (2020). Species-level quota concentration in the Icelandic harvesting sector. Marine Policy, 104108.

6. Gunnlaugsson, S. B., \& Agnarsson, S. (2019). Late arrival: The development of resource rent in Icelandic fisheries. Fisheries Research, 214, 126-135.

7. Flaaten, O., Heen, K., \& Matthíasson, T. (2017). Profit and resource rent in fisheries. Marine Resource Economics, 32(3), 311-328.

8. Bjarnadóttir, B. B., Minelgaite, I. \& Cook, D. (forthcoming). The tone was set in the past: Sustainability in new product development within the Icelandic marine industry. Ocean and Coastal Management (IN REVIEW).

9. Saviolidis, N. M., Davíðsdóttir, B., Ilmola, L., Stepanova, A., Valman, M., \& Rovenskaya, E. (2020). Realising blue growth in the fishing industry in Iceland and Norway: Industry perceptions on drivers and barriers to blue growth investments and policy implications. Marine Policy, 117, 103967.

10. Chambers, C., \& Carothers, C. (2017). Thirty years after privatization: A survey of Icelandic small-boat fishermen. Marine Pol$i c y, 80,69-80$.

11. Chambers, C., Einarsson, N., \& Karlsdóttir, A. (2020a). Small-scale fisheries in Iceland: Local voices and global complexities. In Small-Scale Fisheries in Europe: Status, Resilience and Governance (pp. 329-349). Springer, Cham.

12. Kokorsch, M., \& Benediktsson, K. (2018). Prosper or perish? The development of Icelandic fishing villages after the privatisation of fishing rights. Maritime Studies, 17(1), 69-83.

13. Landssamband smábátaeigenda (National Association of Small Boat Owners). (2016). Afli smábáta sá hæsti í sögunni. Retrieved July 3rd, 2020, from: http://www.smabatar.is/2016/10/afli-smabata-sa-haesti-i-sogun.shtm

14. Pórðarson, G. \& Viðarsson, J. (2014). Coastal fisheries in Iceland. Report no. 12-14 by Matís ehf. Retrieved September 22nd, 2020 from: https:/www.matis.is/media/matis/utgafa/12-14Coastal-fisheries-in-Iceland.pdf

15. Chambers, C., Henke, T., Barr, B., Cook, D., Costa Pierce, B., Einarsson, N., Kaiser, B., Knutsson, Ö, Kokorsch, M., Nazarova, N. \& Sutton, T. (2020b). Fisheries and aquaculture in the Arctic. In D. Natcher, \& T. Koivurova (Eds.), Renewable Economies in the Arctic: A State of Knowledge Sustainable Development Working Group: Arctic Council.

16. Béné, C., Macfadyen, G., \& Allison, E. H. (2007). Increasing the contribution of small-scale fisheries to poverty alleviation and food security (Report No. 481). FAO Technical Guidelines for Responsible Fisheries. Food \& Agriculture Organisation of the United Nations, Rome. Retrieved September 30th, 2020 from: http://www.fao.org/3/a-a0237e.pdf

17. Gunnlaugsson, S. B., Agnarsson, S., Kristófersson, D. M. \& Ishimura, G. (forthcoming). Derby versus ITQ: Iceland's coastal fisheries explained and compared to its ITQ-managed fisheries. Ocean and Coastal Management.

18. Abernethy, K. E., Allison, E. H., Molloy, P. P., \& Côté, I. M. (2007). Why do fishers fish where they fish? Using the ideal free distribution to understand the behaviour of artisanal reef fishers. Canadian Journal of Fisheries and Aquatic Sciences, 64(11), 15951604.

19. de Melo Alves Damasio, L., Lopes, P. F. M., Pennino, M. G., Carvalho, A. R., \& Sumaila, U. R. (2016). Size matters: fishing less and yielding more in smaller-scale fisheries. ICES Journal of Marine Science, 73(6), 1494-1502. 
20. Villasante, S., Pierce, G. J., Pita, C., Guimeráns, C. P., Rodrigues, J. G., Antelo, M., ... \& Sumaila, U. R. (2016). Fishers' perceptions about the EU discards policy and its economic impact on small-scale fisheries in Galicia (North West Spain). Ecological Economics, 130, 130-138.

21. Gunnarsson, V. I. (2001). Meðhöndlun á fiski um borð í fiskiskipum. Sjávarútvegspjónustan ehf. Retrieved August 7th, 2020, from: https://sjavarutvegur.is/wp-content/uploads/2016/12/VIG2001-medhondlunafiski.pdf

22. Brunsson, N., Rasche, A. \& Seidl, D. (2009). "The Dynamics of Standardization". Organization studies. Organization Studies. doi:10.1177/0170840609104565

23. Sporer, E., \& Little, M. A. (2012). Gemba Kaizen: A commonsense approach to a continuous improvement strategy. $2^{\text {nd }}$ Edition. NY: McGraw-Hill Education.

24. Carnerud, D., Jaca, C., \& Bäckström, I. (2018). Kaizen and continuous improvement-trends and patterns over 30 years. The TQM Journal.

25. Goyal, S., \& Law, E. (2019). An introduction to Kaizen in health care. British journal of hospital medicine, 80(3), 168-169.

26. Prayuda, R. Z. (2020). Continuous Improvement Through Kaizen In An Automotive Industry. Journal of Industrial Engineering \& Management Research, 1(1), 37-42.

27. Lög um stjórn fiskveiða/The Fisheries Management Act no. 116/2006 as amended 82/2013.

28. Fiskistofa. (n.d.). About fisheries management. Retrieved June 29th, 2020, from: http://www.fiskistofa.is/fiskveidistjorn/stjornfiskveida/

29. Sævaldsson, H. and Valtýsson, H. P. (Eds.). (2017). Skip og útgerð við Ísland. Íslenskur sjávarútvegur-Auðlind úr hafinu á alpjóðamarkaði (experimental version, April, 2017). Akureyri: The University of Akureyri's Fisheries program.

30. Viðarsson, J., Einarsson, M. I., Ragnarsson, S. Ö., Laksá, U., Danielsen, R. Iversen, A., Henriksen, E., Berthelsen, T., Manuel, H., Brown, T., Decker, D., Lund, H. S., Larsen, B. \& Ottosson, C-A. (2018). Nordic coastal fisheries and communities - status and future prospects. Report by the Nordic Council of Ministers. Retrieved September 22nd, 2020 from: https://norden.diva-portal.org/smash/get/diva2:1184848/FULLTEXT01.pdf

31. Matís. (2015). Inngangur að fisktækni: Fjölbreyttar og gagnlegar upplýsingar um framleiðslu sjávarafurða.

Retrieved July 8th, 2020, from: http://www.matis.is/media/frettir/Fisktaekni_2.pdf

32. Tryggvason, D. (2017). Áhrif fallhæða á ísfisktogurum á gæði og nýtingarhlutfall afla (BS thesis).

University of Akureyri, Faculty of Natural Resources. Retrieved September 1st, 2020, from: https://skemman.is/bitstream/1946/27939/1/lok\%20dt\%20.pdf

33. Pálsson, P.G. (2015). Ferskfiskbókin: Fjölbreyttar og gagnlegar upplýsingar um framleiðslu á kældum fiski. Matís ohf.

34. UN (United Nations). (2015). Transforming Our World: The 2030 Agenda for Sustainable Development.

UN Publishing: New York. Retrieved September 23rd, 2020 from: https://sustainabledevelopment.un.org/post2015/transformingourworld

35. Said, A., \& Chuenpagdee, R. (2019). Aligning the sustainable development goals to the small-scale fisheries guidelines: A case for EU fisheries governance. Marine Policy, 107, 103599.

36. MENR (Ministry of Environment and Natural Resources). (2018). Iceland's Climate Action Plan for 2018-2030.

Retrieved September 22nd, 2020 from: https://www.government.is/lisalib/getfile.aspx?itemid=5b3c6c45-f326-11e8-942f-005056bc4d74

37. Gray, C. F. and Larson, E. W. (2018). Project Management: The Managerial Process. New York, NY: McGraw-Hill Education.

38. Lock, D. (2003). Project Management, 8th ed. New York, NY: Gower, Aldershot.

39. Hedrick, T. E., Bickman, L. and Rog, D. J. (1993). Applied Research Design: A Practical Guide. California, USA: SAGE Publications.

40. Ásbjörnsson, V. (2017, June 2nd). Cod Fishing in Iceland [video]. Retrieved July 22nd, 2020 from: https://www.YouTube.com/watch?v=RRglfho3vbw\&t 
41. Geirdal, G. G. (2019, January 21st). Handfraveiðar // hand line fishing [video].

Retrieved July 24th, 2020 from: https:/www.YouTube.com/watch?v=SwHTcJeYNuk

42. Jónsson, V. Ö. (2017). Extreme Cod Fishing in Iceland [video]. Retrieved July 22nd, 2020 from:

https://www.YouTube.com/watch?v=1mAws_-kFy8

43. Magnússon, O. Ö. (2013, August 5th). Extreme Cod sea fishing in Iceland [video]. Retrieved July 23rd, 2020

from: https://www.YouTube.com/watch?v=FbtWCGBoo74

44. Martin, K. and Osterling, M. (2013). Value Stream Mapping: How to Visualize Work and Align Leadership for Organizational Transformation. New York, NY: McGraw-Hill Education.

45. Creswell, J.W. (2014). Research Design. Qualitative, Quantitative, and Mixed Methods Approaches. (4th ed.). California: Sage Publications.

46. Bryman. A., \& Bell. E. (2007). Business Research Methods, 2nd edition. Oxford: OUP.

47. Íslenski sjávarklasinn (Icelandic Ocean Cluster). (2018). Greining Íslenska sjávarklasans; Heill sé pér porskur. Retrieved August 7th, 2020, from http://www.sjavarklasinn.is/

48. Matís. (2010). Mikilvægi góðrar meðhöndlunar á fiski. Retrieved September 1st, 2020, from: https://www.matis.is/media/matis/utgafa/Mikilvaegi-godrar-medhondlunar-a-fiski.pdf

49. Ward, J. L. (2010). Dictionary of Project Management Terms 3rd edition. Arlington, Virginia: ESI International. 